\title{
Assessing the effects of management and hydro-edaphic conditions on rice in contrasting East African wetlands using experimental and modelling approaches
}

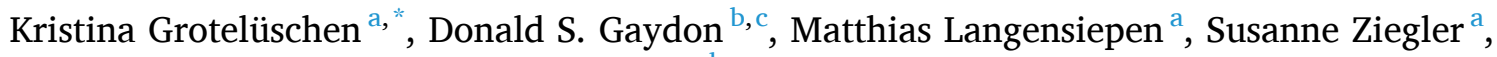 \\ Julius Kwesiga $^{a}$, Kalimuthu Senthilkumar ${ }^{\mathrm{d}}$, Anthony M. Whitbread ${ }^{\mathrm{e}}$, Mathias Becker ${ }^{\mathrm{a}}$ \\ ${ }^{\text {a }}$ Institute of Crop Science and Resource Conservation (INRES), University of Bonn, Bonn, Germany \\ ${ }^{\mathrm{b}}$ CSIRO Agriculture and Food, Brisbane, Australia \\ ${ }^{c}$ School of Agriculture and Food Sciences, University of Queensland, Brisbane, Australia \\ ${ }^{\mathrm{d}}$ Africa Rice Center (AfricaRice), P.O. Box 1690, 101 Antananarivo, Madagascar \\ ${ }^{\mathrm{e}}$ International Crops Research Institute for the Semi-Arid Tropics (ICRISAT), P.O. Box 34441, Dar es Salaam, Tanzania
}

\section{A R T I C L E I N F O}

\section{Keywords:}

APSIM

Floodplain

Inland valley

Oryza spp.

Tanzania

Uganda

\begin{abstract}
A B S T R A C T
Lowland rice yields in East Africa remain low despite favourable hydro-edaphic conditions as benefits from improved cultural management vary between and within wetland types and interactions are poorly understood. Hence, multi-year agronomic field experiments were established to assess the differential responses of lowland rice to management (rainfed 0 and $60 \mathrm{~kg} \mathrm{~N} \mathrm{ha}^{-1}$, and irrigated $120 \mathrm{~kg} \mathrm{~N} \mathrm{ha}^{-1}+60 \mathrm{~kg} \mathrm{PK} \mathrm{ha}^{-1}$ ) and field position within a floodplain in Tanzania (fringe and middle positions) and an inland valley in Uganda (valley-fringe, midvalley and valley-bottom positions). We then calibrated and validated the Agricultural Production System Simulator (APSIM), evaluated the importance of external water table data as model input and assessed the relative effects of water and $\mathrm{N}$ stress on yield as affected by wetland type and field position. Yields of 3.2-9.2 Mg $\mathrm{ha}^{-1}$ were attained in the floodplain and of $1.9-6.3 \mathrm{Mg} \mathrm{ha}^{-1}$ in the inland valley, highlighting the substantial scope to boost yields beyond current regional means of around $2 \mathrm{Mg} \mathrm{ha}^{-1}$. The model estimated grain yields in both wetlands well within the experimental uncertainty during model validation $\left(n=12, \mathrm{r}^{2}=0.76\right.$, RMSEa= $0.92 \mathrm{Mg} \mathrm{ha}^{-1}$ in the floodplain; $n=18, \mathrm{r}^{2}=0.71, \mathrm{RMSEa}=0.72 \mathrm{Mg} \mathrm{ha}^{-1}$ in the inland valley). Results further emphasised the importance of external water table data for sound model performance as they evidently alleviated seasonal droughts. Simulated abiotic stress patterns additionally highlighted hydro-edaphic differences from field positioning within and between both wetlands. While low soil $\mathrm{N}$ was generally the main yield constraint, water stress was comparably more pronounced in the inland valley and supplemental irrigation thus more beneficial on yield. Hydro-edaphic field conditions favoured rice production in the floodplain's fringe with comparably lower $\mathrm{N}$ stress, while large spatial-temporal variabilities prevented a distinct delineation based on toposequential field positions in the inland valley.
\end{abstract}

\section{Introduction}

Over recent decades, rice (Oryza spp.) has become a major staple food across East Africa and is now considered a key commodity for achieving regional food security (Nasrin et al., 2015) and alleviating rural poverty (Balasubramanian et al., 2007). Wetlands are particularly suited for lowland rice production due to sustained water supply from high seasonal rainfall and/or seasonally shallow water tables, and relatively fertile soils (Kijima et al., 2012), and have thus increasingly become the focus of agricultural intensification efforts (Nhamo et al., 2014).

In East Africa (Kenya, Rwanda, Tanzania and Uganda), wetlands cover an area of about 0.17 million $\mathrm{km}^{2}, 80 \%$ of which are comprised of alluvial floodplains and inland valley swamps (Leemhuis et al., 2016), and were thus our selected focal sites. The Kilombero floodplain is Tanzania's most important lowland rice-growing area. Rice production is largely concentrated in the alluvial fans and depends on seasonal rainfall and overbank flooding of the Kilombero River and its tributaries

\footnotetext{
* Correspondence to: Karlrobert-Kreiten-Straße 13, 53115 Bonn, Germany.

E-mail address: k.grotelueschen@posteo.de (K. Grotelüschen).
} 
(Kato, 2007). In central Uganda, swampy bottomlands of small inland valleys are the main rice-producing environments and production depends on seasonal rainfall and subsurface interflows from adjacent valley slopes (van Campenhout et al., 2016). At both sites, farms tend to be small (0.5-2 ha) and average yields are low, with 1.8-2.2 $\mathrm{Mg} \mathrm{ha}^{-1}$ in the floodplain in Tanzania (Senthilkumar et al., 2018) and 1.8-1.9 Mg $\mathrm{ha}^{-1}$ in the inland valleys in central Uganda (Haneishi et al., 2013). In smallholder farming systems, yields are often constrained by economical, social and ecological factors, resulting in inadequate management practices, e.g., inappropriate varietal selection (Kafiriti et al., 2003), untimely weeding (Rodenburg et al., 2015), poor field levelling and water control (Rodenburg, 2013), and consequently in large regional yield gaps (Senthilkumar et al., 2020). However, soil nitrogen (N) deficiency is reportedly the main culprit of low yields and is exacerbated by low external N application rates (Haefele et al., 2013; Saito et al., 2019). While improved crop and field management are likely to substantially increase lowland rice productivity (Saito et al., 2013), variable hydro-edpahic and rainfall conditions have shown to differentially affect rainfed lowland rice yields and yield variability within wetlands, both in inland valleys (Touré et al., 2009), and floodplains (Kwesiga et al., 2019; Senthilkumar et al., 2021). Particularly shallow water tables have been recognised to alleviate production risks from variable seasonal rainfall in rainfed systems (Worou et al., 2012), and to reduce water requirements in irrigated systems (Schmitter et al., 2015). Indiscriminate agricultural wetland use, however, should be avoided and production potentials carefully balanced against potential negative impacts on ecosystem functions (Dixon and Wood, 2003). Additionally, wetland use plans should consider hydro-edpahic conditions to boost regional yields and reduce yield variability.

Crop models are potentially useful tools to analyse such complex environmental interactions in cropping systems and assess crop performances (Holzworth et al., 2014). From a range of available rice models, including CERES-Rice (Godwin and Singh, 1991) and EPIC (Jones et al., 1991), the Agricultural System Simulator (APSIM) (Keating et al., 2003) was selected for this study. The APSIM model was selected as the generic manager module provides the flexible simulation environment needed to freely code and combine system particulars and describe management interventions (Holzworth et al., 2014). Additionally, APSIM has a proven track record in simulating diverse cropping systems worldwide, e.g., oilseed rape in Germany (Hoffmann et al., 2015) and soybean-wheat systems on long-term soil organic carbon sequestration in India (Mohanty et al., 2020). In rice-based systems, APSIM has, for example, been used to assess the effects of improved water management practices on rice yields in Sri Lanka (Amarasingha et al., 2017) and on rice-maize systems in India (Dutta et al., 2020).

Despite the increasing importance of wetlands for regional rice production and the relative advantage of model applications as decisionsupport tools to identify site-specific production constraints and optimum management practices (Balwinder-Singh et al., 2016), modelling studies on differential yield responses to imposed management practices and relative positioning within the wetland are currently lacking. However, in order to derive at sound management recommendations, the ability of APSIM to simulate rice growth and development under variable hydro-edaphic field conditions and in response to imposed management practices requires evaluation. Therefore, the objectives of this study were (i) to parameterise, calibrate and validate the APSIM model for improved local rice varieties, and diverse environmental conditions and management treatments and (ii) to subsequently use the validated model to help understand the relative effects of management and hydro-edaphic field conditions on rice yields and yield determinants in a floodplain and an inland valley wetland of East Africa.

\section{Material and methods}

\subsection{Study sites}

Field experiments were conducted between 2014 and 2017 in (i) an alluvial floodplain, i.e., the Kilombero floodplain near Ifakara in southcentral Tanzania $\left(8.10^{\circ}-8.18^{\circ} \mathrm{S}\right.$ and $36.67^{\circ}-36.76^{\circ} \mathrm{E}, 255$ masl), and (ii) an inland valley swamp at the National Crops Resources Research Institute (NaCRRI) near Namulonge in central Uganda $\left(0.519^{\circ}-0.522^{\circ} \mathrm{N}\right.$ and $32.640^{\circ}-32.644^{\circ} \mathrm{E}, 1105$ masl) (Fig. 1). The floodplain lies at about 300 masl and covers around $7967 \mathrm{~km}^{2}$ (Näschen et al., 2018). Besides the Kilombero River, a vast network of tributaries causes seasonal flooding from overbank flow (Dinesen, 2016). The topography in central Uganda is undulating, ranging from 900 to 1340 masl and is characterised by inland valleys occupied with narrow swampy bottomlands (Miyamoto et al., 2012). The studied inland valley covers $4.5 \mathrm{~km}^{2}$ and is one of the headwater micro-catchments of the Lake Kyoga basin (Gabiri et al., 2020).

\subsubsection{Climate}

The climate at the study sites is sub-humid tropical and humid tropical in the floodplain and the inland valley, respectively (Leemhuis et al., 2016). In the floodplain, annual rainfall of $1200-1400 \mathrm{~mm}$ is received in a largely mono-modal pattern from December to May (Näschen et al., 2018). In the inland valley, mean annual rainfall of about $1200 \mathrm{~mm}$ is received in a bi-modal pattern from September to November and from March to May (Nsubuga et al., 2011). During the main rice-growing periods from 1980 to 2010, monthly mean daily maximum and minimum temperatures ranged from $31.9^{\circ}$ to $28.9^{\circ} \mathrm{C}$ and $22.1^{\circ}$ to $20.0^{\circ} \mathrm{C}$ between March and May in the floodplain, and from $28.4^{\circ}$ to $28.3^{\circ} \mathrm{C}$ and $17.1^{\circ}$ to $16.6^{\circ} \mathrm{C}$ between September and November in the inland valley (Ruane et al., 2015). Daily rainfall (mm), maximum and minimum temperatures $\left({ }^{\circ} \mathrm{C}\right)$ and solar radiation $\left(\mathrm{MJ} \mathrm{m}^{-2}\right.$ ) were recorded by automatic weather stations near Ifakara town in Tanzania $\left(8.06^{\circ} \mathrm{S}\right.$ and $\left.36.39^{\circ} \mathrm{E}\right)$ and at the NaCRRI in Uganda $\left(0.522^{\circ} \mathrm{N}\right.$ and $32.642^{\circ} \mathrm{E}$ ) from 2014 to 2017 . Additional tipping buckets were installed at the respective field positions to monitor the within-site rainfall variability more precisely.

\subsection{Experimental design}

Experiments were established along the hydrological gradient in the floodplain, i.e., at the fringe and middle positions based on the origin, extent and duration of floodwater (Kwesiga et al., 2019), and as a toposequence valley cross-section in the inland valley, i.e., at the valley-fringe, mid-valley and valley-bottom positions (Gabiri et al., 2017). A randomised complete block design with four replications per treatment and field position was used and established for three consecutive years, i.e., from 2015 to 2017 in the floodplain and from 2014 to 2016 in the inland valley. Management treatments included: (i) a rainfed non-amended baseline treatment $(0 \mathrm{~N})$, (ii) a rainfed $60 \mathrm{~kg} \mathrm{~N}$ $\mathrm{ha}^{-1}$ treatment $(60 \mathrm{~N})$, and (iii) a manually irrigated, $120 \mathrm{~kg} \mathrm{~N}^{-1}$ and $60 \mathrm{~kg} \mathrm{PK} \mathrm{ha}^{-1}$ attainable yield treatment $(120 \mathrm{~N}+\mathrm{PK}+\mathrm{I})$ (Kwesiga et al., 2019). $\mathrm{N}$ was applied as urea-N in two splits, with $75 \%$ and $50 \%$ being applied basally and $25 \%$ and $50 \%$ at panicle initiation (PI) in the floodplain and the inland valley, respectively. As per local recommendations, P was applied basally as single superphosphate in the floodplain and as triple superphosphate in the inland valley, while $\mathrm{K}$ was applied basally as muriate of potash. Manual supplemental irrigation aimed at maintaining near-saturated soil conditions from transplanting to ripening stages. Individual plots measured $5 \times 6 \mathrm{~m}$ and were levelled, puddled and bunded $(40 \times 20 \mathrm{~cm}$ height and width). Weeds were removed manually at 3, 6 and 9 weeks after transplanting. With the onset of the rainy seasons in February in the floodplain and August in the inland valley, rice nurseries were established and experimental plots were ploughed with hand hoes, puddled, and levelled. Two 

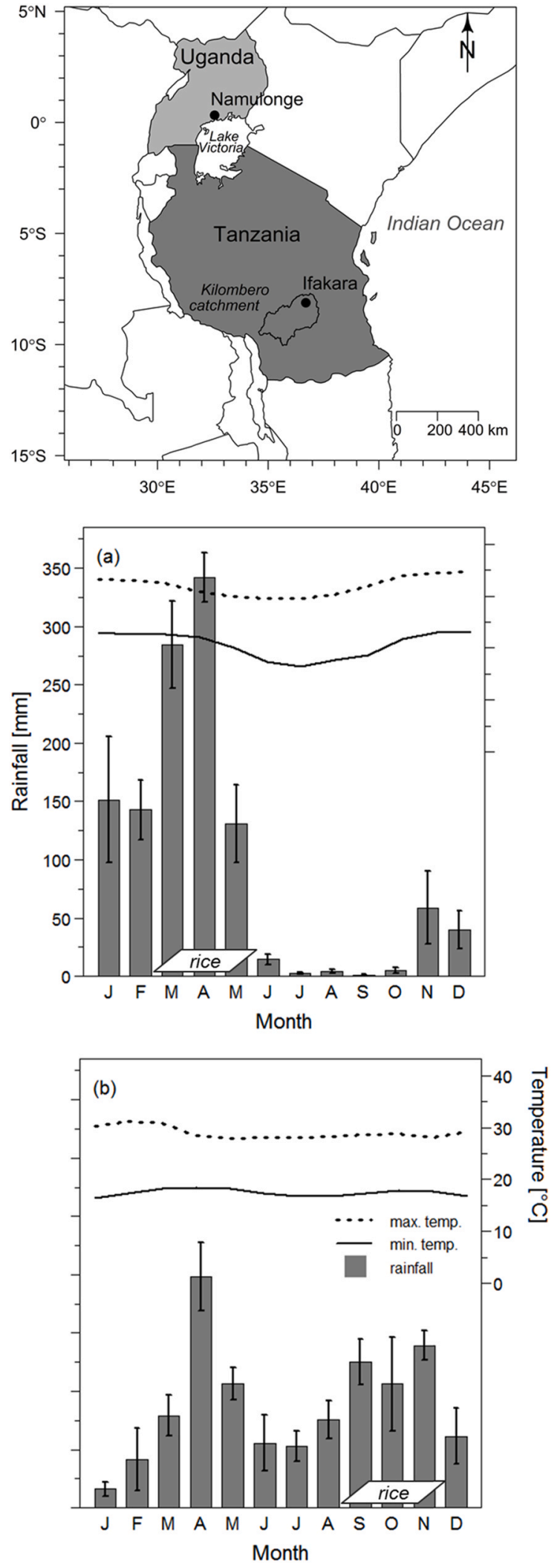

Fig. 1. Geographical location of the study sites in the floodplain in south-east Tanzania and the inland valley in central Uganda (left), and average monthly rainfall, minimum and maximum temperatures during the study period (right) at the study sites in (a) the floodplain (2015-2017, $n=3$ ) and (b) the inland valley $(2014-2017, n=4)$. Bars indicate standard errors of monthly rainfall means, boxes indicate the main rice-growing periods in the floodplain (March to May) and the inland valley (September to November). 16-30-day-old seedlings per hill were transplanted at $20 \times 20 \mathrm{~cm}$ spacing in the floodplain, and three $21-27$-day-old seedlings per hill at $15 \times 30$ $\mathrm{cm}$ spacing in the inland valley. Recommended, potentially high-yielding and locally available rice genotypes were used, i.e., the semi-dwarf, 120-day lowland rice (O. sativa) variety SARO-5 (Singh et al., 2013) in the floodplain, and the drought tolerant, 95-110-day rainfed rice (O. sativa x O. glaberrima) variety NERICA-4 (Jones et al., 1997 ) in the inland valley. Sequential biomass accumulation and rice $\mathrm{N}$ uptake were determined at the early vegetative, PI, 50\% flowering and physiological maturity stages from $2 \times 6$ opposing hill clusters outside the central harvest area. Phenological key stages, i.e., PI, 50\% flowering and physiological maturity were observed by primordial initiation, emergence of $50 \%$ of panicles and yellow-colouring of $90 \%$ of grains, respectively (De Datta, 1981). Plants were partitioned into individual organs and oven-dried at $90{ }^{\circ} \mathrm{C}$ until constant weight. Rice $\mathrm{N}$ uptake was determined by analysing ground dry matter sub-samples for their $\mathrm{N}$ content and multiplication with their weight as described in Kwesiga et al. (2020a). Central harvest areas for grain yield determination (reported at $0 \%$ moisture content) measured $6 \mathrm{~m}^{2}$ in the floodplain and $5 \mathrm{~m}^{2}$ in the inland valley.

\subsubsection{Hydro-edaphic characteristics}

Predominant soils were Fluvisols in the floodplain (Gabiri et al., 2018) and Gleysols in the inland valley (Gabiri et al., 2017). The Fluvisols were of alluvial origin and generally heavy-textured. Topsoil organic carbon $\left(\mathrm{C}_{\text {org }}\right)$ contents varied between $25 \mathrm{~g} \mathrm{~kg}^{-1}$ in the fringe and $7 \mathrm{~g} \mathrm{~kg}^{-1}$ in the middle position (Table 1$)$. The soil $\mathrm{N}\left(\mathrm{N}_{\text {tot }}\right)$ content was low and only slightly above the critical $\mathrm{N}$ content for rice growth of $2 \mathrm{~g} \mathrm{~kg}^{-1}$ (Senthilkumar et al., 2018). The Gleysols were mostly of colluvial origin with an umbric horizon and largely loamy-textured although texture and nutrient contents varied considerably within and among field positions (Gabiri et al., 2017). Topsoil $\mathrm{C}_{\text {org }}$ and $\mathrm{N}_{\text {tot }}$ contents were higher compared to the floodplain Fluvisols, with up to $57 \mathrm{~g} \mathrm{C} \mathrm{kg}^{-1}$ and $8 \mathrm{~g} \mathrm{~N} \mathrm{~kg}^{-1}$ (Table 1). At both sites, plant-available $\mathrm{P}$ and exchangeable $\mathrm{K}$ were largely sufficient for rice growth, exceeding the critical limit for rice growth of $<8 \mathrm{mg} \mathrm{P} \mathrm{kg}^{-1}$ and $<60 \mathrm{mg} \mathrm{K} \mathrm{kg}^{-1}$ according to Mehlich-3 soil extraction (Kwesiga et al., 2019). A detailed description of soil analysis methods is provided by Kwesiga et al. (2020a).

In the floodplain, annual water tables fluctuated between surface level and $1.5 \mathrm{~m}$ below surface at the fringe, between $1 \mathrm{~m}$ above and $3 \mathrm{~m}$ below surface at the middle position, and between $0.6 \mathrm{~m}$ above and $0.9 \mathrm{~m}$ below surface across all field positions in the inland valley (Figure A.1). Flooding occurred from April to July in the floodplain and from October to January and April to June in the inland valley (Figure A.1). At all field positions, daily water table depths and volumetric soil moisture contents (10 and $30 \mathrm{~cm}$ depth) were aggregated from hourly piezometer pressure logger and Frequency-DomainReflectometry (FDR) profile probe data, respectively. A detailed instrumentation description is provided by Gabiri et al., (2018, 2019). Due to continuous pressure data logger failure in the floodplain's fringe position in 2017, data from 2015 were used. Remaining missing data were filled using the Kalman imputation method (Moritz and Bartz-Beielstein, 2017).

\subsection{The APSIM model ( $v 7.5)$}

APSIM is a daily time-step, point-scale cropping system model that uses a modular design around a central engine to drive the simulation process and ensure the communication between all modules, and is described in detail by Holzworth et al. (2014). In this study, key modules included the rice module ORYZA (Gaydon et al., 2012a) that was developed based on physiological routines of the ORYZA2000 model (Bouman et al., 2001), and the POND module (Gaydon et al., 2012b) that simulates key chemical and biological processes under temporarily or permanently ponded conditions. Other modules included SOILWAT 
Table 1

Topsoil properties of the Fluvisols in the floodplain and the Gleysols in the inland valley used for APSIM parameterisation.

\begin{tabular}{|c|c|c|c|c|c|c|c|c|c|c|c|}
\hline Site & Field position & $\begin{array}{l}\text { Depth } \\
{[\mathrm{cm}]}\end{array}$ & $\begin{array}{l}\mathrm{BD} \\
{\left[\mathrm{g} \mathrm{cm}^{-3}\right]}\end{array}$ & $\begin{array}{l}\text { LL15 } \\
{\left[\mathrm{cm}^{3} \mathrm{~cm}^{-3}\right]}\end{array}$ & $\begin{array}{l}\text { DUL } \\
{\left[\mathrm{cm}^{3} \mathrm{~cm}^{-3}\right]}\end{array}$ & $\begin{array}{l}\text { SAT } \\
{\left[\mathrm{cm}^{3} \mathrm{~cm}^{-3}\right]}\end{array}$ & $\begin{array}{l}\text { Soil texture } \\
{[\text { WRB }]}\end{array}$ & $\begin{array}{l}\mathrm{C}_{\text {org }} \\
{\left[\mathrm{g} \mathrm{kg}^{-1}\right]}\end{array}$ & $\begin{array}{l}\mathrm{N}_{\text {tot }} \\
{\left[\mathrm{g} \mathrm{kg}^{-1}\right]}\end{array}$ & $\begin{array}{l}\text { fBiom } \\
{[0,1]}\end{array}$ & $\begin{array}{l}\text { fInert } \\
{[0,1]}\end{array}$ \\
\hline \multirow[t]{8}{*}{ Floodplain, Tanzania } & \multirow[t]{3}{*}{ fringe } & $0-20$ & 1.05 & 0.198 & 0.364 & 0.501 & loam & 24.51 & 1.21 & 0.040 & 0.620 \\
\hline & & $20-35$ & 1.30 & 0.240 & 0.370 & 0.508 & clay-loam & 14.21 & 0.91 & 0.030 & 0.650 \\
\hline & & $35-50$ & 1.41 & 0.248 & 0.373 & 0.468 & clay-loam & 11.63 & 0.81 & 0.020 & 0.700 \\
\hline & \multirow[t]{5}{*}{ middle } & $0-20$ & 1.34 & 0.137 & 0.237 & 0.401 & sandy-loam & 6.54 & 0.50 & 0.070 & 0.350 \\
\hline & & $20-25$ & 1.30 & 0.223 & 0.354 & 0.508 & clay-loam & 9.27 & 0.71 & 0.060 & 0.400 \\
\hline & & $25-28$ & 1.34 & 0.299 & 0.393 & 0.494 & clay & 12.05 & 0.91 & 0.060 & 0.450 \\
\hline & & $28-37$ & 1.33 & 0.337 & 0.397 & 0.498 & clay & 12.20 & 1.11 & 0.015 & 0.500 \\
\hline & & $37-46$ & 1.30 & 0.337 & 0.401 & 0.509 & clay & 11.74 & 0.91 & 0.010 & 0.550 \\
\hline \multirow[t]{10}{*}{ Inland valley, Uganda } & \multirow[t]{4}{*}{ valley-fringe } & $0-23$ & 0.97 & 0.205 & 0.380 & 0.479 & clay-loam & 45.71 & 3.51 & 0.040 & 0.700 \\
\hline & & $23-30$ & 1.13 & 0.201 & 0.304 & 0.390 & clay-loam & 33.13 & 2.17 & 0.030 & 0.750 \\
\hline & & $30-35$ & 1.33 & 0.152 & 0.298 & 0.497 & loam & 13.86 & 0.62 & 0.020 & 0.850 \\
\hline & & $35-45$ & 1.68 & 0.093 & 0.175 & 0.366 & sandy-loam & 3.15 & 0.31 & 0.015 & 0.900 \\
\hline & \multirow[t]{3}{*}{ mid-valley } & $0-20$ & 1.05 & 0.212 & 0.371 & 0.514 & clay-loam & 28.90 & 2.27 & 0.040 & 0.420 \\
\hline & & $20-30$ & 1.44 & 0.181 & 0.301 & 0.526 & loam & 9.14 & 0.72 & 0.030 & 0.450 \\
\hline & & $30-45$ & 1.51 & 0.216 & 0.327 & 0.430 & clay-loam & 3.34 & 0.41 & 0.020 & 0.500 \\
\hline & \multirow[t]{3}{*}{ valley-bottom } & $0-22$ & 1.10 & 0.208 & 0.420 & 0.520 & clay & 57.02 & 5.26 & 0.040 & 0.780 \\
\hline & & $22-34$ & 1.09 & 0.257 & 0.401 & 0.474 & clay-loam & 27.62 & 2.06 & 0.030 & 0.750 \\
\hline & & $34-48$ & 1.57 & 0.139 & 0.245 & 0.408 & sandy-clay-loam & 3.74 & 0.31 & 0.020 & 0.850 \\
\hline
\end{tabular}

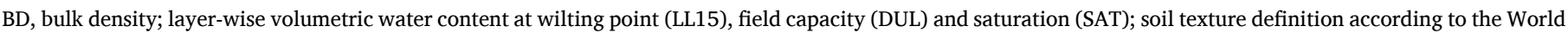

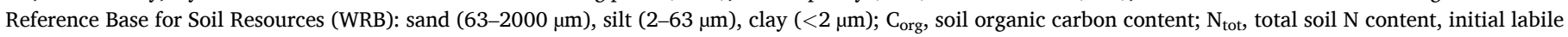
(fBiom) and inert (fInert) fraction of soil organic carbon.

for soil water balancing, SOILN for soil $\mathrm{C}$ and $\mathrm{N}$ transformations and SURFACEOM for the fate and conversion of surface residues (Probert et al., 1998).

\subsubsection{APSIM parameterisation, calibration and validation protocol}

APSIM was run continuously as a rice-fallow system for three-years without re-setting soil $\mathrm{N}$, soil water and soil organic matter (SOM) parameters after initialisation at both study sites. Using the replications average per field position and treatment, the third season of experimental data was used for model calibration and determination of genotype-specific parameters and coefficients, while the two remaining seasons of independent experimental data were used for model validation. Considering all field positions and management treatments, observed vs. simulated key phenological stages, biomass accumulation and partitioning, $\mathrm{N}$ uptake, and grain yields were statistically compared.

\subsubsection{APSIM parameterisation and calibration}

Following the parameterisation procedure as set out by Gaydon et al. (2021), APSIM requires empirical local input data to drive the simulation process, i.e., daily climate such as minimum and maximum temperatures $\left({ }^{\circ} \mathrm{C}\right)$, solar radiation $\left(\mathrm{MJ} \mathrm{m}^{-2}\right)$ and rainfall $(\mathrm{mm})$. Additionally, measurable soil physical and chemical parameters are required, i.e., layer-wise $\mathrm{pH}$, bulk density, and soil volumetric water contents at saturation (SAT), field capacity (DUL) and permanent wilting point (LL15), as well as initial soil organic carbon $\left(\mathrm{C}_{\text {org }}\right)$ and mineral $\mathrm{N}\left(\mathrm{NO}_{3}{ }^{-}, \mathrm{NH}_{4}{ }^{+}\right)$contents (Table 1$)$. Macroflow conductivity and the vertical water flow through macropores was specified by measured saturated percolation rates (Ks, mm day ${ }^{-1}$ ), while soil water conductivity, i.e., the proportion of water exceeding DUL and draining daily into the subsequent soil layer is specified via the swcon coefficient. Swcon varies depending on soil texture, i.e., typically $<0.5$ for heavy clay and $>0.8$ for sandy soils from greater water conductivity (Probert et al., 1998). Not directly measurable parameters required iterative calibration as described below.

2.3.2.1. Crop phenology and assimilate partitioning. Following Jones and Kiniry (1986), APSIM uses growing degree days (GDD; ${ }^{\circ} \mathrm{C}$ day $^{-1}$ ) to determine the phenological development of rice, explained by Bouman and Van Laar (2006). Genotype-specific GDD constants and partitioning coefficients for SARO-5 and NERICA-4 were calibrated from observed key phenological stages and corresponding biomass accumulation and partitioning data. Similarly, field data was used to determine leaf maximum and minimum relative growth rates, maximum individual grain weight at maturity, and specific leaf area. Results were further fine-tuned to match observed data best (Table A.1).

2.3.2.2. SOM mineralization. APSIM requires initial layer-wise soil organic carbon $\left(\mathrm{C}_{\text {org }}\right), \mathrm{NO}_{3}{ }^{-}$and $\mathrm{NH}_{4}{ }^{+}$contents as well as parameter values for fBiom (fraction of soil microbial biomass (biom)) and fInert (fraction of inert humic material (hum)) to initialise the proportions of SOM pools and their mineralisation capacities, i.e., the fresh organic matter (fom), the more labile biom and the more inert hum pools. Values for fInert and fBiom were incrementally adjusted within physically plausible bounds (Probert et al., 1998), and until observed and simulated crop yields of the non-amended baseline treatment $(0 \mathrm{~N})$ provided a good match (Table 1). Additionally, APSIM was set to treat residues and weeds according to field management, i.e., incorporation in mid-November in the floodplain and full aboveground removal after rice harvest in the inland valley. Following field observations, APSIM's weed cultivar 'perennial_grass' was planted and allowed to grow during the fallow period before being incorporated during field preparation.

2.3.2.3. Ponding and water table dynamics. Vertical water flow was restricted at around $30 \mathrm{~cm}$ depth to account for the plough-pan under puddled conditions and Ks values calibrated by matching observed and simulated ponds and soil water contents. In APSIM, ponded conditions and perched water tables result from restricted vertical water flow and in-situ rainfall and/or irrigation. Maximum pond depth is user-defined (max_pond) and excess water subjected to runoff, while a perched water table is defined as the proportion of soil water between DUL and SAT in a soil layer directly adjacent to a saturated layer (Asseng et al., 1998). In wetlands, however, water tables are mutually affected by in-situ rainfall and/or irrigation and catchment-scale processes (rainfall, lateral and subsurface inflows) (Leemhuis et al., 2016). Therefore, we used daily measured water table data to drive the simulation process. Variable aquifer depths and soil properties in the inland valley, however, caused high spatial-temporal water table fluctuations within field positions (Gabiri et al., 2017). Therefore, plot-level soil moisture measurements were assumed to be the better indicator for local soil water conditions. Thus, daily measured water tables were adjusted by a fixed factor within the aquifer range, i.e., lowered daily by 32,3 and $30 \mathrm{~cm}$ in the valley-fringe, mid-valley and valley-bottom position, respectively. 


\subsubsection{APSIM validation}

Occasionally, poor initial validation performance required revisitation of parameterisation and calibration procedures, until acceptable model performance was achieved, i.e., within the experimental uncertainty. APSIM's ability to simulate cropping system 'carry-over' effects was further evaluated, i.e., continuous comparison of observed and simulated soil moisture contents, and soil carbon dynamics and indigenous soil $\mathrm{N}$ supply via non-amended baseline yields $(0 \mathrm{~N})$ without seasonal re-setting of variables after initialisation.

\subsubsection{APSIM water and $N$ deficit factors}

APSIM calculates crop water and $\mathrm{N}$ deficit factors to simulate the effects of water and $\mathrm{N}$ stress on crop growth and development. Following model validation, daily water and $\mathrm{N}$ stress factors were, therefore, used to assess the relative effects of wetland type and field position on rice yields ( $1=$ no stress, $0=$ severe stress). While water stress (lestrs) is calculated as a function of the upper and lower soil-water tensions in the root zone, i.e., water deficits from actual to potential soil water contents (Boling et al., 2007), $\mathrm{N}$ stress (rnstrs) is calculated from crop $\mathrm{N}$ contents, i.e., $\mathrm{N}$ deficits from the ratio of potential (ancrpt) to actual (ancr) crop $\mathrm{N}$ content (Bouman and Van Laar, 2006). Both water and $\mathrm{N}$ stress affect the rate of relative leaf growth, i.e., reducing the relative leaf growth and thus the rates of photosynthesis and yield up until flowering, while accelerating leaf senesence after flowering. A detailed description of the processes and modelling logics is provided in Bouman et al. (2001).

\subsection{Statistical analysis}

Paired observed $\left(\mathrm{O}_{\mathrm{i}}\right)$ and simulated $\left(\mathrm{S}_{\mathrm{i}}\right)$ data-points were combined to determine the slope $(\alpha)$, intercept $(\beta)$ and coefficient of determination $\left(\mathrm{r}^{2}\right)$ of the linear regression. A slope $\alpha$ of 0 , and intercept $\beta$ and $\mathrm{r}^{2}$ of 1 indicate a perfect model fit. The Student's $t$-test of means was used assuming unequal variance; a $\mathrm{P}(\mathrm{t}) \geq 0.05$ indicates no significant differences exist between observed and simulated values. Additional statistical measures included the absolute and normalised root mean square error (RMSEa, Mg ha ${ }^{-1}$ Eq. (1), and RMSEn, \%, Eq. (2)), modelling efficiency (EF, -, Eq. (3)), and the mean absolute error (MAE, Mg ha' ${ }^{-1}$, Eq. (4)) (Hagi-Bishow and Bonnell, 2000; Willmott and Matsuura, 2005):

$$
\begin{aligned}
& \text { RMSEa }=\sqrt{\sum_{\mathrm{i}=1}^{n}\left(\mathrm{O}_{\mathrm{i}}-\mathrm{S}_{\mathrm{i}}\right)^{2} / n} \\
& \text { RMSEn }=\sqrt{\sum_{\mathrm{i}=1}^{n}\left(\mathrm{O}_{\mathrm{i}}-\mathrm{S}_{\mathrm{i}}\right)^{2} / n * 100 / \overline{\mathrm{O}}} \\
& \mathrm{EF}=1-\sum_{\mathrm{i}=1}^{n}\left(\mathrm{~S}_{\mathrm{i}}-\mathrm{O}_{\mathrm{i}}\right)^{2} / \sum_{\mathrm{i}=1}^{n}\left(\mathrm{O}_{\mathrm{i}}-\overline{\mathrm{O}}\right)^{2} \\
& \mathrm{MAE}=\sum_{\mathrm{i}=1}^{n}\left|\mathrm{~S}_{\mathrm{i}}-\mathrm{O}_{\mathrm{i}}\right| / n
\end{aligned}
$$

where $S_{i}$ and $\mathrm{O}_{\mathrm{i}}$ are the simulated and observed values, respectively; and $n$ equals the number of data-pairs and $\bar{O}$ the mean of the observed values. The RMSEa is ideally similar to or smaller than the standard deviation (SD) of the observed values while the RMSEn is ideally similar to the coefficient of variation (CV) of the observed values. The EF value compares the simulated values to the mean of the observed values. EF of 1 indicates a perfect model fit and equals a mean squared error (MSE) of 0 , while a value of 0 indicates the MSE is equal to the variability of the observed data. A negative EF value indicates that the mean of the observed data is a better predictor than the model. The MAE shows the absolute difference of simulated to observed values; a MAE of 0 denoting a perfect model fit and positive or negative MAEs the quantification of model over- or underestimation. Where applicable, multiple mean comparisons were performed using the Tukey's HSD test at a 95\% confidence level.

\section{Results}

\subsection{Seasonal weather conditions}

Annual rainfall during the study period ranged between 1060 and $1319 \mathrm{~mm}$ in the floodplain (2015-2017) and between 775 and $1300 \mathrm{~mm}$ in the inland valley (2014-2017) (Fig. 1). During the main rice-growing periods from March to May, 790, 562 and $918 \mathrm{~mm}$ of rainfall were received at the floodplain's fringe, and 701, 537 and $1033 \mathrm{~mm}$ at the floodplain's middle position in 2015, 2016 and 2017, respectively. In the El Niño year of 2016, irregular rainfall patterns were observed. While the rainy season started comparably early and about $493 \mathrm{~mm}$ were received in January and February alone, the rains also ceased early with only about $30 \mathrm{~mm}$ being received in May. In the inland valley, 332, 519 and $233 \mathrm{~mm}$ of rainfall were received during the main rice-growing periods (September to November) in 2014, 2015, and 2016, respectively. Low seasonal rainfall of 2016 was most pronounced in October where only $35 \mathrm{~mm}$ were received against 84 and $243 \mathrm{~mm}$ in 2014 and 2015, respectively. Daily maximum and minimum temperatures varied only slightly during the rice-growing periods, with averages of $33.4^{\circ}$ and $21.1^{\circ} \mathrm{C}$ in the floodplain, and $28.6^{\circ}$ and $17.7^{\circ} \mathrm{C}$ in the inland valley, respectively (Fig. 1).

\subsection{Rice yields in contrasting lowland systems}

Rice grain yields varied between 1.9 and $9.2 \mathrm{Mg} \mathrm{ha}^{-1}$, depending on wetland type, field position, year and treatment. Yields were generally lower in the inland valley than the floodplain, with mean yields of 3.8 and $6.2 \mathrm{Mg} \mathrm{ha}^{-1}$, respectively. Rainfall variability led to higher mean yields of $6.3 \mathrm{Mg} \mathrm{ha}^{-1}$ with favourable rainfall conditions in 2017 and to lower mean yields of $5.6 \mathrm{Mg} \mathrm{ha}^{-1}$ with unfavourable rainfall conditions in 2016 in the floodplain. Similarly, mean yields of 4.6 in 2014 and of $3.2 \mathrm{Mg} \mathrm{ha}^{-1}$ in 2016 were related to variable seasonal rainfall in the inland valley. Toposequential yield trends were not significant in the inland valley, while yields were significantly higher in the floodplain's fringe (6.5 Mg ha ${ }^{-1}$ ) as compared to the middle position ( $5.9 \mathrm{Mg} \mathrm{ha}^{-1}$ ) (Table 2). Baseline yields of non-amended rice $(0 \mathrm{~N})$ were higher in the floodplain ( $4 \mathrm{Mg} \mathrm{ha}^{-1}$ ) than the inland valley $\left(2.7 \mathrm{Mg} \mathrm{ha}^{-1}\right)$, and more so in the floodplain's fringe $\left(4.3 \mathrm{Mg} \mathrm{ha}^{-1}\right)$ than middle position $\left(3.8 \mathrm{Mg} \mathrm{ha}^{-1}\right.$ ). In both wetlands, rice responded significantly to applied mineral $\mathrm{N}$ fertiliser (Table 2). Mean attainable yields were 8.7 and $7.6 \mathrm{Mg} \mathrm{ha}^{-1}$ in the floodplain's fringe and middle position, respectively, and about $5.2 \mathrm{Mg} \mathrm{ha}^{-1}$ with little variation among field positions in the inland valley.

\subsection{APSIM calibration and validation}

Model veracity was assessed by statistically comparing observed and simulated soil moisture dynamics and crop parameters, i.e., phenology, sequential biomass accumulation and partitioning, $\mathrm{N}$ uptake and grain yield in response to wetland type, field position and management treatment.

\subsubsection{Crop phenology}

APSIM underestimated key phenological stages of the lowland rice variety SARO-5 in Tanzania during model calibration on average by 5 days for flowering and overestimated maturity by 2 days (Figure A.2). During model validation, the upper whiskers indicated large deviations of $>20$ days to flowering and $>11$ days to maturity, while the median indicated deviations of 11 and 2 days to flowering and maturity, respectively. In Uganda, time to flowering and maturity of the rainfed rice variety NERICA- 4 was underestimated on average by $<7$ days during both model calibration and validation (Figure A.2). 
Table 2

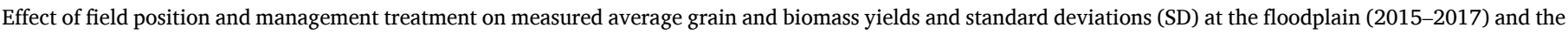
inland valley (2014-2016) sites. Values are the means of four replicates.

\begin{tabular}{|c|c|c|c|c|c|c|c|c|c|c|c|}
\hline \multirow[t]{2}{*}{ Site } & \multirow{2}{*}{\multicolumn{2}{|c|}{ Source of variation }} & \multirow[t]{2}{*}{$n$} & \multirow{3}{*}{$\begin{array}{l}\text { Grain } \\
\text { yield } \\
\text { (SD) } \\
{[\mathrm{Mg}} \\
\left.\mathrm{ha}^{-1}\right]\end{array}$} & \multirow{2}{*}{$\begin{array}{l}\text { Biomass } \\
\text { yield (SD) } \\
{\left[\mathrm{Mg} \mathrm{ha}^{-1}\right]}\end{array}$} & \multirow[t]{2}{*}{ Site } & \multicolumn{2}{|l|}{ Source of variation } & \multirow[t]{2}{*}{$n$} & \multirow{2}{*}{$\begin{array}{l}\text { Grain } \\
\text { yield } \\
\text { (SD) } \\
{[\mathrm{Mg}} \\
\left.\mathrm{ha}^{-1}\right]\end{array}$} & \multirow{2}{*}{$\begin{array}{l}\text { Biomass } \\
\text { yield (SD) } \\
\mathrm{CMg} \mathrm{ha}^{-1}\end{array}$} \\
\hline & & & & & & & & & & & \\
\hline \multirow[t]{16}{*}{$\begin{array}{r}\text { Floodplain, } \\
\text { Tanzania }\end{array}$} & $\begin{array}{l}\text { Field position } \\
\text { (FP) }\end{array}$ & & & & & $\begin{array}{l}\text { Inland } \\
\text { valley, }\end{array}$ & $\begin{array}{l}\text { Field position } \\
\text { (FP) }\end{array}$ & & & & \\
\hline & & fringe & 36 & $\begin{array}{l}6.5 \\
(2.0)\end{array}$ & $13.0(4.0)$ & Uganda & & valley-fringe & 36 & $\begin{array}{l}3.9 \\
(1.4)\end{array}$ & $10.0(3.3)$ \\
\hline & & middle & 36 & $\begin{array}{l}5.9 \\
(1.7)\end{array}$ & $12.1(4.1)$ & & & mid-valley & 36 & $\begin{array}{l}3.6 \\
(1.5)\end{array}$ & $9.5(4.1)$ \\
\hline & & & & & & & & valley-bottom & 36 & $\begin{array}{l}3.9 \\
(1.5)\end{array}$ & $10.2(3.6)$ \\
\hline & $\begin{array}{l}\text { Management } \\
\text { treatment }(\mathrm{M})\end{array}$ & & & & & & $\begin{array}{l}\text { Management } \\
\text { treatment }(\mathrm{M})\end{array}$ & & & & \\
\hline & & $0 \mathrm{~N}$ & 24 & $\begin{array}{l}4.0 \\
(0.8)\end{array}$ & $8.5(1.4)$ & & & $0 \mathrm{~N}$ & 36 & $\begin{array}{l}2.7 \\
(1.0)\end{array}$ & $7.2(2.4)$ \\
\hline & & $60 \mathrm{~N}$ & 24 & $\begin{array}{l}6.3 \\
(0.7)\end{array}$ & $12.2(2.1)$ & & & $60 \mathrm{~N}$ & 36 & $\begin{array}{l}3.5 \\
(1.1)\end{array}$ & $9.1(2.8)$ \\
\hline & & $120 \mathrm{~N}+\mathrm{PK}+\mathrm{I}$ & 24 & $\begin{array}{l}8.1 \\
(0.9)\end{array}$ & $17.0(2.7)$ & & & $120 \mathrm{~N}+\mathrm{PK}+\mathrm{I}$ & 36 & $\begin{array}{l}5.2 \\
(1.1)\end{array}$ & $13.4(2.6)$ \\
\hline & Year & & & & & & Year & & & & \\
\hline & & 2015 & 24 & $\begin{array}{l}6.5 \\
(1.8)\end{array}$ & $12.1(3.5)$ & & & 2014 & 36 & $\begin{array}{l}4.6 \\
(1.4)\end{array}$ & $11.2(3.7)$ \\
\hline & & 2016 & 24 & $\begin{array}{l}5.6 \\
(1.9)\end{array}$ & $11.2(3.8)$ & & & 2015 & 36 & $\begin{array}{l}3.5 \\
(1.0)\end{array}$ & $10.0(2.5)$ \\
\hline & & 2017 & 24 & $\begin{array}{l}6.3 \\
(1.7)\end{array}$ & $14.3(4.3)$ & & & 2016 & 36 & $\begin{array}{l}3.2 \\
(1.6)\end{array}$ & $8.5(4.2)$ \\
\hline & $\begin{array}{l}\text { Anova } \\
\text { probabilities for } \\
\text { the effects of }\end{array}$ & & & & & & $\begin{array}{l}\text { Anova } \\
\text { probabilities for } \\
\text { the effects of }\end{array}$ & & & & \\
\hline & & Field position (FP) & 72 & 0.010 & NS & & & $\begin{array}{l}\text { Field position } \\
\text { (FP) }\end{array}$ & 108 & NS & NS \\
\hline & & Management (M) & 72 & 0.001 & 0.001 & & & $\begin{array}{l}\text { Management } \\
\text { (M) }\end{array}$ & 108 & 0.001 & 0.001 \\
\hline & & $\mathrm{FP} \times \mathrm{M}$ & 144 & 0.100 & NS & & & $\mathrm{FP} \times \mathrm{M}$ & 216 & NS & NS \\
\hline
\end{tabular}

SD, standard deviation; $N S$, not significant.

\subsubsection{Biomass accumulation and grain yield}

During model validation, observed and simulated values correlated strongly at both study sites, showing a small MAE of $<0.5 \mathrm{Mg} \mathrm{ha}^{-1}$ for grain and biomass yields (Table 3). In the floodplain, an RMSEa of 0.92 $\mathrm{Mg} \mathrm{ha}{ }^{-1}$ for grain and of $1.71 \mathrm{Mg} \mathrm{ha}^{-1}$ for biomass yield compared favourably to the SD among the observed data $\left(1.84 \mathrm{Mg} \mathrm{ha}^{-1}\right.$ for grain and $3.36 \mathrm{Mg} \mathrm{ha}^{-1}$ for biomass yield). Additionally, simulated and observed grain and biomass yields correlated strongly, i.e., with an $\mathrm{r}^{2}$ $=0.76, \alpha=0.82$ and $\beta=1.20$ for grain and an $r^{2}=0.76, \alpha=0.75$ and $\beta=3.40$ for biomass yield. Sound model performance was further endorsed by EF values of 0.75 and 0.74 for grain and biomass yield, respectively. In the inland valley, an RMSEa of $0.78 \mathrm{Mg} \mathrm{ha}^{-1}$ for grain and $1.42 \mathrm{Mg} \mathrm{ha}^{-1}$ for biomass yield compared similarly well to the SD among the observed data $\left(1.11 \mathrm{Mg} \mathrm{ha}^{-1}\right.$ for grain and $2.46 \mathrm{Mg} \mathrm{ha}^{-1}$ for biomass yield). Observed and simulated data-pairs also showed a strong correlation for grain and biomass yield $\left(\mathrm{r}^{2}=0.71\right.$ and 0.72$)$ with low bias ( $\alpha=0.91$ and $0.88, \beta=0.79$ and 1.60 ), respectively. Furthermore, an EF of 0.51 and 0.67 for grain and biomass yields, respectively, supported sound model performance. At both study sites and field positions, the paired $t$-test additionally confirmed that no differences exist between simulated and observed non-amended baseline yields $(0 \mathrm{~N})$ (data not shown). Table 3 provides a detailed overview on model performance statistics during calibration and validation.

Additionally, a linear regression of observed and simulated datapairs for grain yield illustrates model performance from both externally supplied and internally simulated perched water tables, and the treatment effect on yield (Fig. 2). In the floodplain, the linear regression from externally supplied water tables showed a strong correlation $\left(\mathrm{r}^{2}=\right.$ $0.94)$ with a low bias $(\alpha=-0.20, \beta=1.08)$, despite indicating a slight overestimation of the $0 \mathrm{~N}$ yield in the fringe and the $120 \mathrm{~N}+\mathrm{PK}+\mathrm{I}$ yield in the middle position (Fig. 2). In contrast, the linear regression from internally simulated perched water tables showed a strong underestimation of yields $(\alpha=-1.95, \beta=0.99)$ and rainfed yields were underestimated on average by $2 \mathrm{Mg} \mathrm{ha}^{-1}$. In the inland valley, model performance from externally supplied water tables showed a similarly strong correlation $\left(\mathrm{r}^{2}=0.88, \alpha=-0.03, \beta=1.1\right)$ and only the midvalley's $60 \mathrm{~N}$ yields were visibly overestimated. Model performance from internally simulated perched water tables, however, also showed a distinct underestimation of rainfed yields across all field positions ( $\alpha=-2.12, \beta=1.49$ ). On average, yields were underestimated by 0.8 $\mathrm{Mg} \mathrm{ha}^{-1}$ that, however, increased to $2.1 \mathrm{Mg} \mathrm{ha}^{-1}$ in 2016 with low seasonal rainfall. Furthermore, standard errors of observed yields were comparably large in the inland valley, indicating a strong seasonal effect on yield (Fig. 2).

\subsubsection{Rice $N$ uptake}

Additionally, a linear regression of observed and simulated datapairs for rice $\mathrm{N}$ uptake at physiological maturity illustrates sounds model performance at both study sites. In the floodplain, the linear regression showed a strong correlation $\left(r^{2}=0.95\right)$ and a high level of accuracy for the non-amended baseline treatment $(0 \mathrm{~N})$, however, indicating an increasing overestimation of rice $\mathrm{N}$ uptake with increasing mineral $\mathrm{N}$ fertiliser application $(\alpha=-14.84, \beta=1.4$ ) (Fig. 3). In the inland valley, model performance showed a similarly strong correlation $\left(\mathrm{r}^{2}=0.79\right)$ with only the mid-valley's $60 \mathrm{~N}$ and $120 \mathrm{~N}+\mathrm{PK}+\mathrm{I}$ rice $\mathrm{N}$ uptake showing a visible overestimation ( $\alpha=-5.56, \beta=1.13)$ (Fig. 3).

\subsubsection{Soil moisture dynamics}

APSIM simulated the measured soil moisture dynamics in the floodplain with a high level of accuracy at 10 and $30 \mathrm{~cm}$ soil depths and 
Table 3

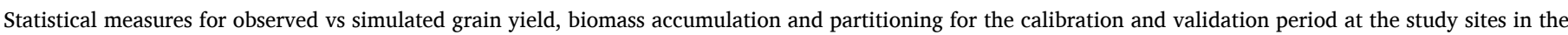
floodplain and the inland valley.

\begin{tabular}{|c|c|c|c|c|c|c|c|c|c|c|c|c|c|c|}
\hline Site & $\begin{array}{l}\text { Model } \\
\text { evaluation }\end{array}$ & Parameter & $n$ & $\begin{array}{l}\text { Xobs (SD) } \\
{[\mathrm{Mg}} \\
\left.\mathrm{ha}^{-1}\right]\end{array}$ & $\begin{array}{l}\text { Ysim (SD) } \\
{[\mathrm{Mg}} \\
\left.\mathrm{ha}^{-1}\right]\end{array}$ & $\alpha[]$ & $\begin{array}{l}\beta \\
{[\mathrm{Mg}} \\
\left.\mathrm{ha}^{-1}\right]\end{array}$ & $\begin{array}{l}\mathrm{r}^{2} \\
{[0,1]}\end{array}$ & $\begin{array}{l}P(t) \\
*\end{array}$ & $\begin{array}{l}\mathrm{CV} \\
{[\%]}\end{array}$ & $\begin{array}{l}\text { RMSEa } \\
{[\mathrm{Mg}} \\
\left.\mathrm{ha}^{-1}\right]\end{array}$ & $\begin{array}{l}\text { RMSEn } \\
{[\%]}\end{array}$ & $\mathrm{EF}[]$ & $\begin{array}{l}\text { MAE } \\
{[\mathrm{Mg}} \\
\left.\mathrm{ha}^{-1}\right]\end{array}$ \\
\hline \multirow[t]{8}{*}{$\begin{array}{r}\text { Floodplain, } \\
\text { Tanzania }\end{array}$} & \multirow[t]{4}{*}{ calibration } & biomass & 6 & $\begin{array}{l}14.29 \\
(4.12)\end{array}$ & $\begin{array}{l}13.31 \\
(4.22)\end{array}$ & 0.96 & -0.47 & 0.88 & 0.19 & 28.8 & 1.75 & 12.3 & 0.82 & -0.98 \\
\hline & & grain & 6 & $\begin{array}{l}6.30 \\
(1.57)\end{array}$ & $\begin{array}{l}6.87 \\
(2.78)\end{array}$ & 1.68 & -3.71 & 0.90 & 0.38 & 25.0 & 1.49 & 30.2 & 0.10 & 0.57 \\
\hline & & stem & 6 & $\begin{array}{l}5.34 \\
(2.15)\end{array}$ & $\begin{array}{l}4.18 \\
(0.96)\end{array}$ & 0.35 & 2.29 & 0.63 & - & 40.2 & 1.90 & 39.0 & 0.21 & -1.16 \\
\hline & & leaf & 6 & $\begin{array}{l}0.90 \\
(0.44)\end{array}$ & $\begin{array}{l}2.09 \\
(0.49)\end{array}$ & 0.59 & 1.55 & 0.29 & - & 49.0 & 1.27 & 141.7 & -7.36 & 1.19 \\
\hline & \multirow[t]{4}{*}{ validation } & biomass & 12 & $\begin{array}{l}11.69 \\
(3.36)\end{array}$ & $\begin{array}{l}12.12 \\
(2.88)\end{array}$ & 0.75 & 3.39 & 0.76 & 0.41 & 28.7 & 1.70 & 14.6 & 0.74 & 0.43 \\
\hline & & grain & 12 & $\begin{array}{l}6.08 \\
(1.84)\end{array}$ & $\begin{array}{l}6.20 \\
(1.75)\end{array}$ & 0.83 & 1.14 & 0.77 & 0.66 & 30.3 & 0.91 & 14.9 & 0.76 & 0.12 \\
\hline & & stem & 12 & $\begin{array}{l}3.79 \\
(1.23)\end{array}$ & $\begin{array}{l}4.01 \\
(1.03)\end{array}$ & 0.70 & 1.37 & 0.69 & - & 32.4 & 0.72 & 18.9 & 0.66 & 0.22 \\
\hline & & leaf & 12 & $\begin{array}{l}1.42 \\
(0.50)\end{array}$ & $\begin{array}{l}1.75 \\
(0.51)\end{array}$ & 0.73 & 0.72 & 0.51 & - & 35.3 & 0.51 & 35.7 & -0.02 & 0.33 \\
\hline \multirow[t]{8}{*}{$\begin{array}{c}\text { Inland valley, } \\
\text { Uganda }\end{array}$} & \multirow[t]{4}{*}{ calibration } & biomass & 9 & $\begin{array}{l}8.52 \\
(3.88)\end{array}$ & $\begin{array}{l}8.08 \\
(3.73)\end{array}$ & 0.88 & 0.55 & 0.85 & 0.44 & 45.6 & 1.58 & 18.5 & 0.83 & -0.44 \\
\hline & & grain & 9 & $\begin{array}{l}3.25 \\
(1.45)\end{array}$ & $\begin{array}{l}3.48 \\
(1.61)\end{array}$ & 1.00 & 0.21 & 0.82 & 0.37 & 44.7 & 0.72 & 22.2 & 0.75 & 0.23 \\
\hline & & stem & 9 & $\begin{array}{l}2.38 \\
(1.04)\end{array}$ & $\begin{array}{l}2.92 \\
(1.32)\end{array}$ & 1.13 & 0.25 & 0.79 & - & 43.9 & 0.83 & 34.7 & 0.37 & 0.54 \\
\hline & & leaf & 9 & $\begin{array}{l}1.40 \\
(0.56)\end{array}$ & $\begin{array}{l}1.62 \\
(0.77)\end{array}$ & 1.28 & -0.17 & 0.86 & - & 39.8 & 0.39 & 28.2 & 0.50 & 0.22 \\
\hline & \multirow[t]{4}{*}{ validation } & biomass & 18 & $\begin{array}{l}10.52 \\
(2.46)\end{array}$ & $\begin{array}{l}10.86 \\
(2.55)\end{array}$ & 0.88 & 1.60 & 0.72 & 0.32 & 23.4 & 1.42 & 13.5 & 0.67 & 0.34 \\
\hline & & grain & 18 & $\begin{array}{l}4.06 \\
(1.11)\end{array}$ & $\begin{array}{l}4.48 \\
(1.20)\end{array}$ & 0.91 & 0.79 & 0.71 & 0.02 & 27.4 & 0.78 & 19.2 & 0.51 & 0.42 \\
\hline & & stem & - & - & - & - & - & - & - & - & - & - & - & - \\
\hline & & leaf & - & - & - & - & - & - & - & - & - & - & - & - \\
\hline
\end{tabular}

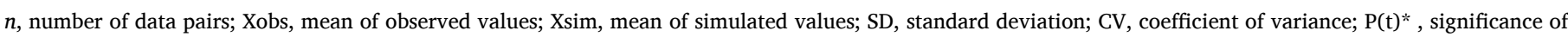

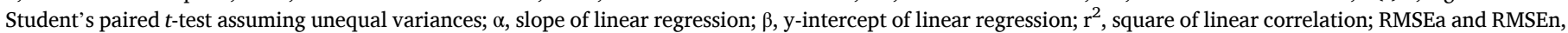
absolute and normalised root mean squared error; EF, modelling efficiency; MAE, mean absolute error.

*values greater than 0.05 indicate simulated and observed values are the same at $95 \%$ confidence level

throughout the 3-year study period, and with $r^{2}$ of 0.87 and 0.81 at $10 \mathrm{~cm}$ depth (Fig. 4) and with $\mathrm{r}^{2}$ of 0.85 and 0.66 at $30 \mathrm{~cm}$ depth (Figure A.3) for the fringe and middle positions, respectively. Soil moisture dynamics in the inland valley were simulated satisfactorily at $10 \mathrm{~cm}$ depth and with $\mathrm{r}^{2}$ of $0.59,0.59$ and 0.45 throughout the study period (Fig. 5), and with $\mathrm{r}^{2}$ of $0.19,0.30$ and 0.36 at $30 \mathrm{~cm}$ depth (Figure A.4) in the valley-fringe, mid-valley and valley-bottom positions, respectively.

\subsection{APSIM water and $N$ stress factors by wetland type and field position}

Wetland type- and field position-specific yield determinants were subsequently examined via APSIM water and $\mathrm{N}$ stress factors in the nonamended baseline treatment $(0 \mathrm{~N})$. In both wetlands, $\mathrm{N}$ stress during the reproductive stage from PI to flowering was more severe and, hence, yield-affecting than water stress. Water stress, however, was more pronounced in the inland valley as compared to the floodplain (Figs. 6, 7). However, $\mathrm{N}$ and water deficits additionally varied as affected by field position and year. During the reproductive stage, $\mathrm{N}$ stress was lower $(<0.3$ at PI) while water stress higher $(<0.85$ at PI) in the floodplain's fringe as compared to the middle position $(<0.1$ for $\mathrm{N}$ stress and $>0.95$ for water stress at PI) (Fig. 6). In toposequential comparison, $\mathrm{N}$ stress was lower $(<0.85$ at PI) and water stress higher ( 0.6 at PI) in the inland valley's valley-fringe position during the reproductive stage (Fig. 7). $\mathrm{N}$ stress subsequently increased from the inland valley's mid-valley $(>0.8$ at PI) to the valley-bottom position ( 0.75 at PI), while water stress decreased from the valley-bottom $(>0.7$ at $\mathrm{PI})$ to the mid-valley position $(>0.8$ at PI).

\section{Discussion}

\subsection{Evaluation of APSIM in contrasting lowland rice systems}

APSIM performed well within the experimental uncertainty at both wetland types, field positions and treatments. Sound model performance was supported by several goodness-of-fit measures, e.g., a RMSEa of 0.92 and $0.78 \mathrm{Mg} \mathrm{ha}^{-1}$ for grain yield, comparing favourably to the observed standard deviation of 1.84 and $1.11 \mathrm{Mg} \mathrm{ha}^{-1}$ in the floodplain and inland valley, respectively. Similarly, total rice $\mathrm{N}$ uptake was simulated at a high level of accuracy particularly in the non-amended baseline treatments at both study sites, with $\mathrm{r}^{2}$ of 0.95 and 0.79 in the floodplain and inland valley, respectively. Furthermore, the paired $t$-test confirmed that observed and simulated non-amended baseline yields were the same at a $95 \%$ confidence level, indicating that soil carbon dynamics and subsequent soil $\mathrm{N}$ supply were simulated accurately, which is considered a key performance criterion for cropping system models in low-input environments (Gaydon et al., 2017).

Despite being a point-scale model, APSIM has further shown to perform accurately both in a temporally highly variable but spatially fairly homogenous floodplain as well as in a spatial-temporal highly heterogeneous inland valley provided external water table data were available as model input. Accurate depiction of soil water conditions in the floodplain, for example, was supported by the high level of accuracy in soil moisture simulation throughout the study period, with $\mathrm{r}^{2}$ exceeding 0.85 in the fringe and 0.65 in the middle positions and in both 10 and $30 \mathrm{~cm}$ soil depth. Without the use of external water table data, APSIM underestimated rainfed rice yields on average by $2 \mathrm{Mg} \mathrm{ha}^{-1}$ in the floodplain and by $0.8 \mathrm{Mg} \mathrm{ha}^{-1}$ in the inland valley that, however, increased to $2.1 \mathrm{Mg} \mathrm{ha}^{-1}$ for the dry 2016 season with only $233 \mathrm{~mm}$ of 


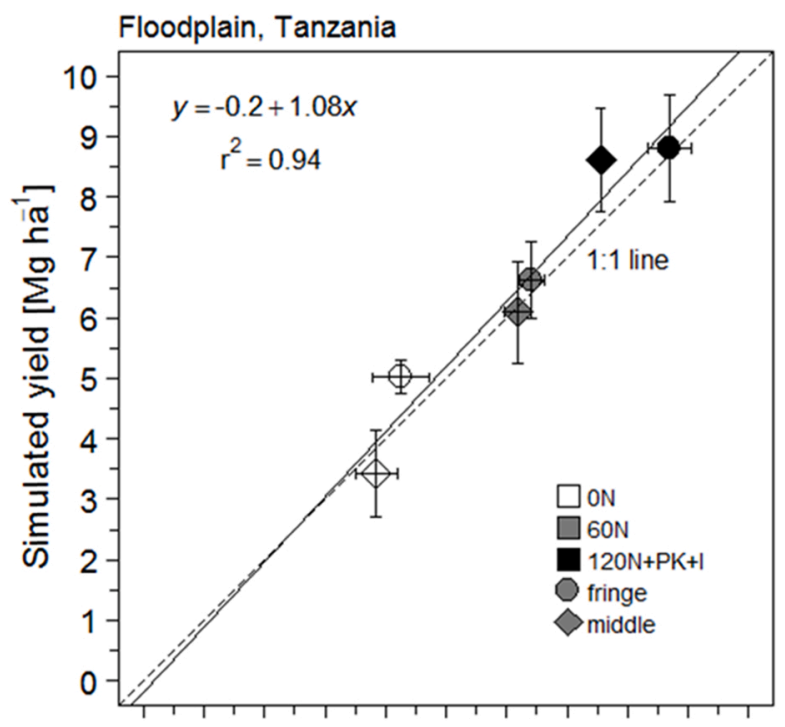

Inland valley, Uganda
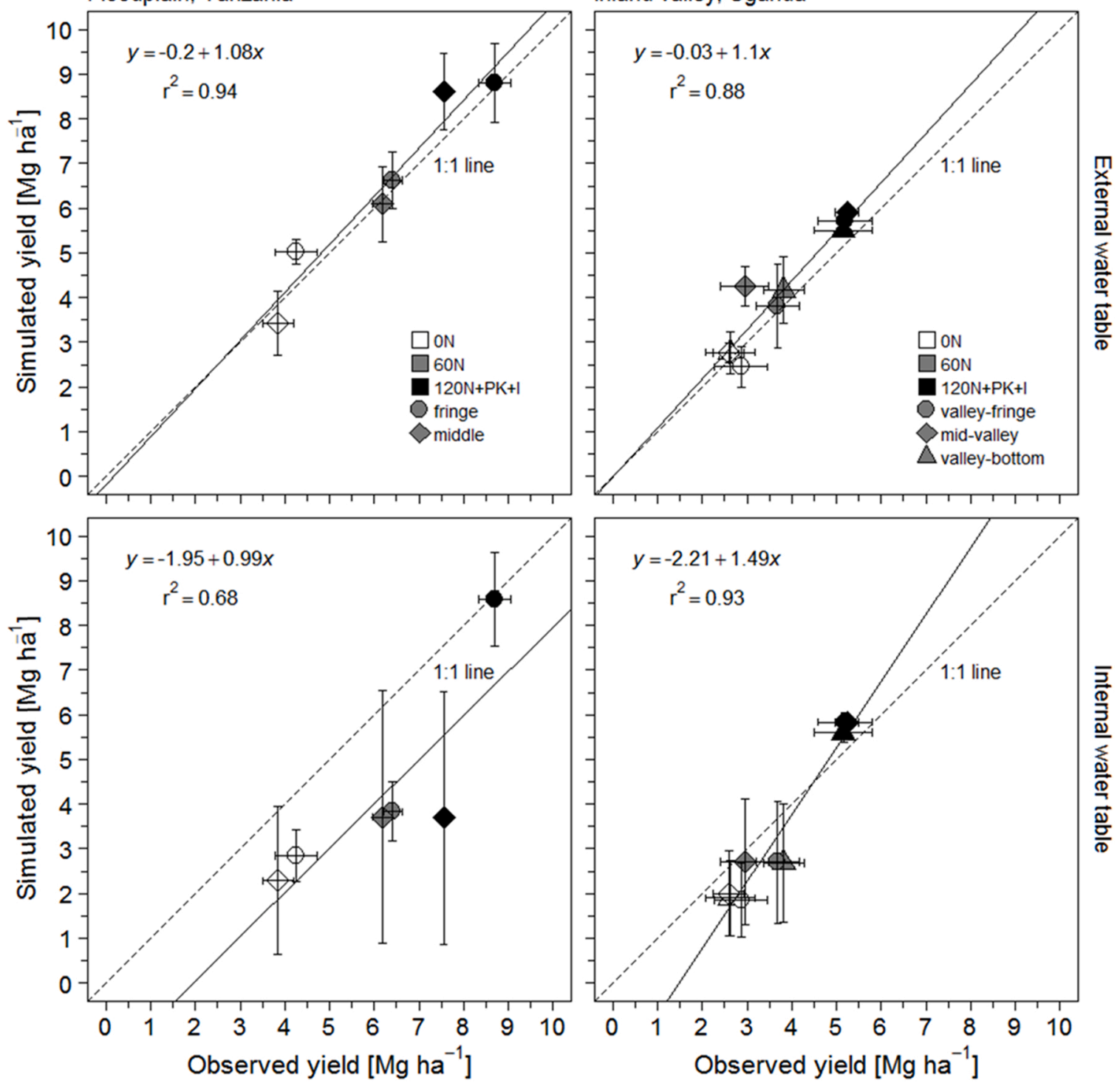

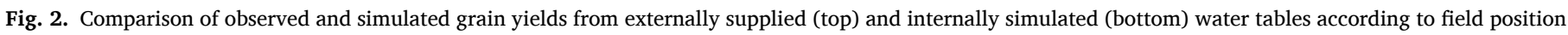

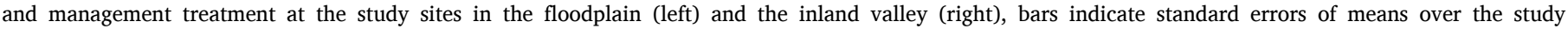
period $(n=3)$.

seasonal rainfall. Therefore, results emphasised the importance of seasonally shallow water tables for rainfed lowland rice production and lowland rice modelling as they evidently mitigated extreme drought events in years of low and variable seasonal rainfall. Similarly, seasonally shallow water tables have shown to supply water for crop growth even during dry seasons in Southeast Asia (Belder et al., 2007), and have been recognised as important water sources in lowland rice systems in West Africa (Schmitter et al., 2015) and China (Cabangon et al., 2004). Modelling lowland rice systems, local water table data may thus be provided from measurements or simulation using hydrological models like Hydrus-1D (Šimůnek et al., 2013).

Reduced predictive accuracy, however, was observed in the simulation of certain phenological key stages in the floodplain and soil moisture dynamics in the inland valley but may be explained from seasonal abnormalities and experimental design limitations. During the El Niño year of 2016, phenological predictions thus showed large deviations ( $>11$ days) of key stages in the floodplain's fringe position. Irregular rainfall amount and distribution in 2016, comparatively early transplantation (about 3 weeks) of old seedlings (30 days) and a prolonged time to flowering and maturity (10-20 additional days) have been reported by Kwesiga et al. (2019). In slightly photoperiod-sensitive varieties, variation in sowing time and seedling age as well as low temperatures have shown to affect the time to flowering and thus maturity (Fukai, 1999). Due to the complexity of irregularities, however, a conclusive explanation of observed phenology is difficult. Serial planting trials could, therefore, help ascertain the interactions of temperature and photoperiod on the phenological development of SARO-5 and hence improve phenological development parameters in APSIM. Overall, however, model predictions were acceptable in $83 \%$ of all observations. In the inland valley, phenological and yield predictions were more accurate than the simulation of soil moisture dynamics, though temporal trends and magnitudes were simulated quite well. In a similar study, Feng et al. (2007) have related inaccurate soil moisture simulation to the time of state variable integration in the model. The time of integration in APSIM is one day and rainfall events may have occurred before or after integration of state variables. Furthermore, inaccurate soil moisture simulation has been related to spatially heterogeneous soil properties in inland valleys in Benin, particularly during dry periods, i. e., from a greater variability in soil properties as compared to crop variables (Worou et al., 2012). While the coefficients of variances in 

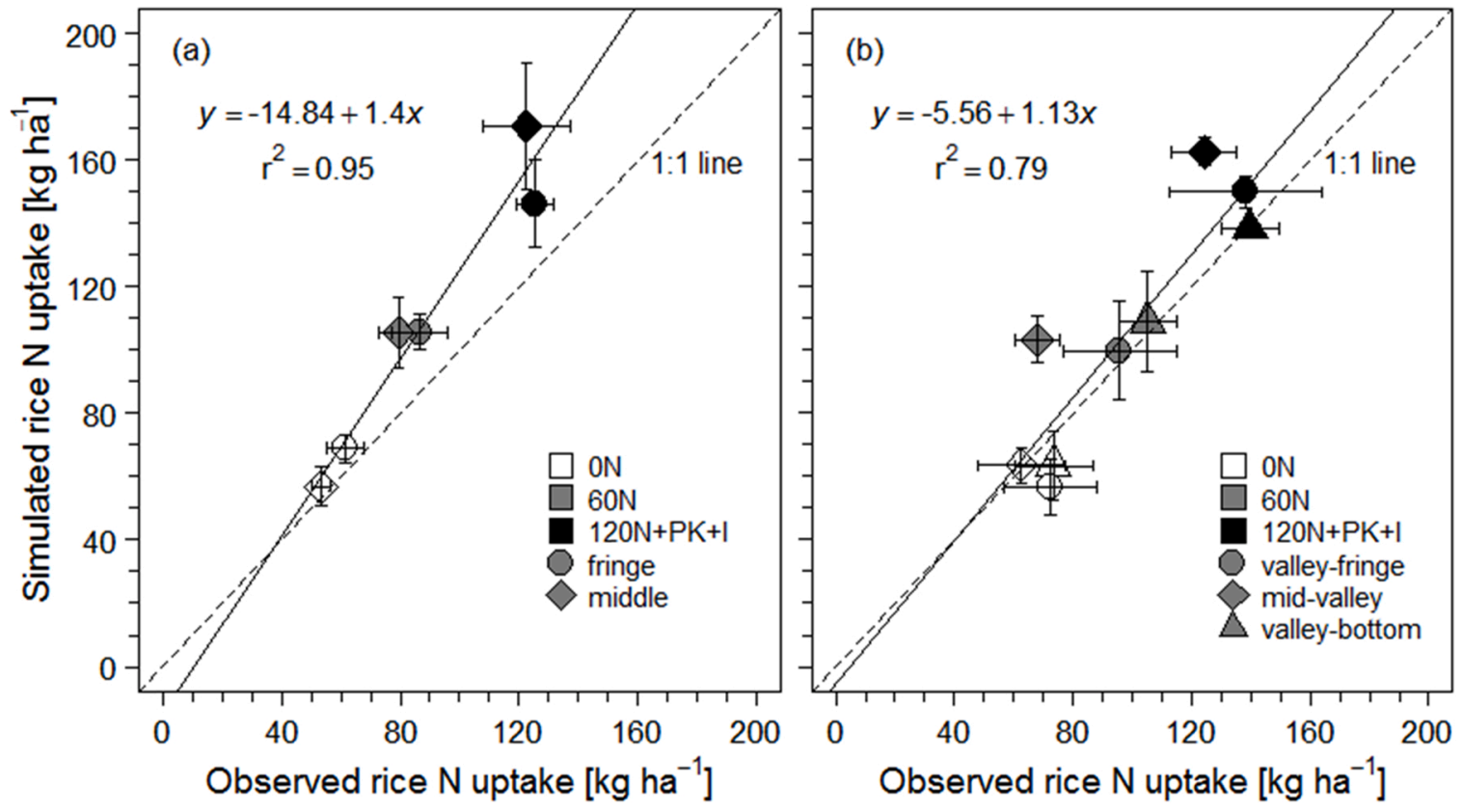

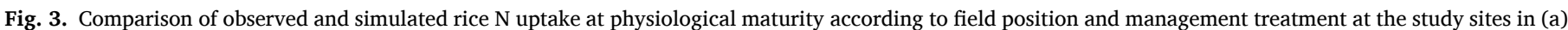
the floodplain and (b) the inland valley, bars indicate standard errors of means over the study period $(n=3)$.

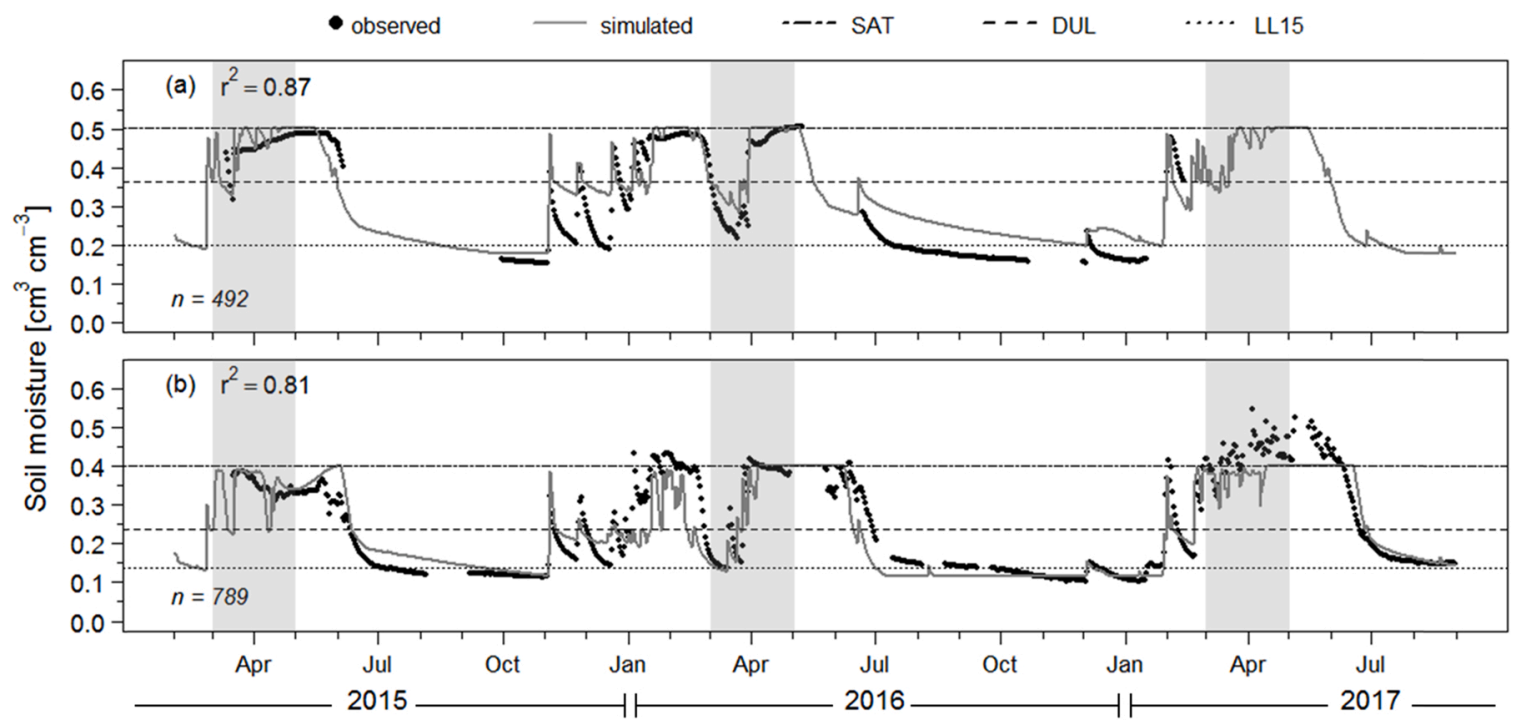

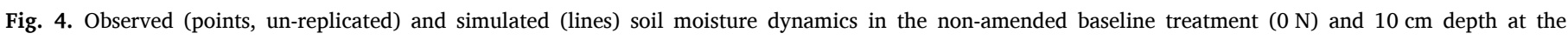

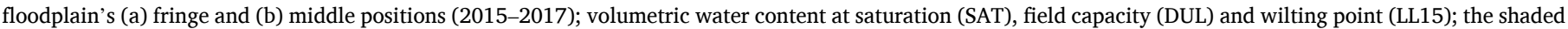
areas (grey) indicate the main rice-growing periods (March to May).

measured crop yields ranged between 33 and 43\%, measured variability in soil properties amounted to $24-80 \%$ (Gabiri et al., 2017). Soil moisture measurements, however, were recorded un-replicated in a discrete field location and not causally related to soil properties, and were thus much harder to simulate at a high level of accuracy. The present study, however, lacked a high spatial resolution of field-level data to systematically explain or avoid such uncertainties. Additionally, lateral and subsurface inflows have shown to be important water balance components in sloped lowlands (Tsubo et al., 2006). In the inland valley. lateral inflows evidently affected topsoil moisture dynamics, particularly in the valley-fringe position (Gabiri et al., 2017) but were not available for model input. We, therefore, recommend to causally relate field-level soil texture, soil moisture, lateral inflow and water table data to improve yield and soil water predictions in highly heterogeneous and sloped lowlands. However, this would require extensive field instrumentation and data collection that might not be feasible for cash-limited research projects.

Despite such uncertainties from field data, APSIM performed well within the experimental uncertainty in both wetlands which is a key measure of acceptable model performance (Gaydon et al., 2017), and suggested that $\mathrm{N} \mathrm{x}$ water stress interactions and their effects on yield were simulated adequately.

\subsection{Effects of wetland type, field position and treatment on yield}

In general, results have shown that improved cultural practices alone (varietal selection, row-transplanting, bunding, levelling and timely weeding) can increase regional yields substantially $\left(4 \mathrm{Mg} \mathrm{ha}^{-1}\right.$ 

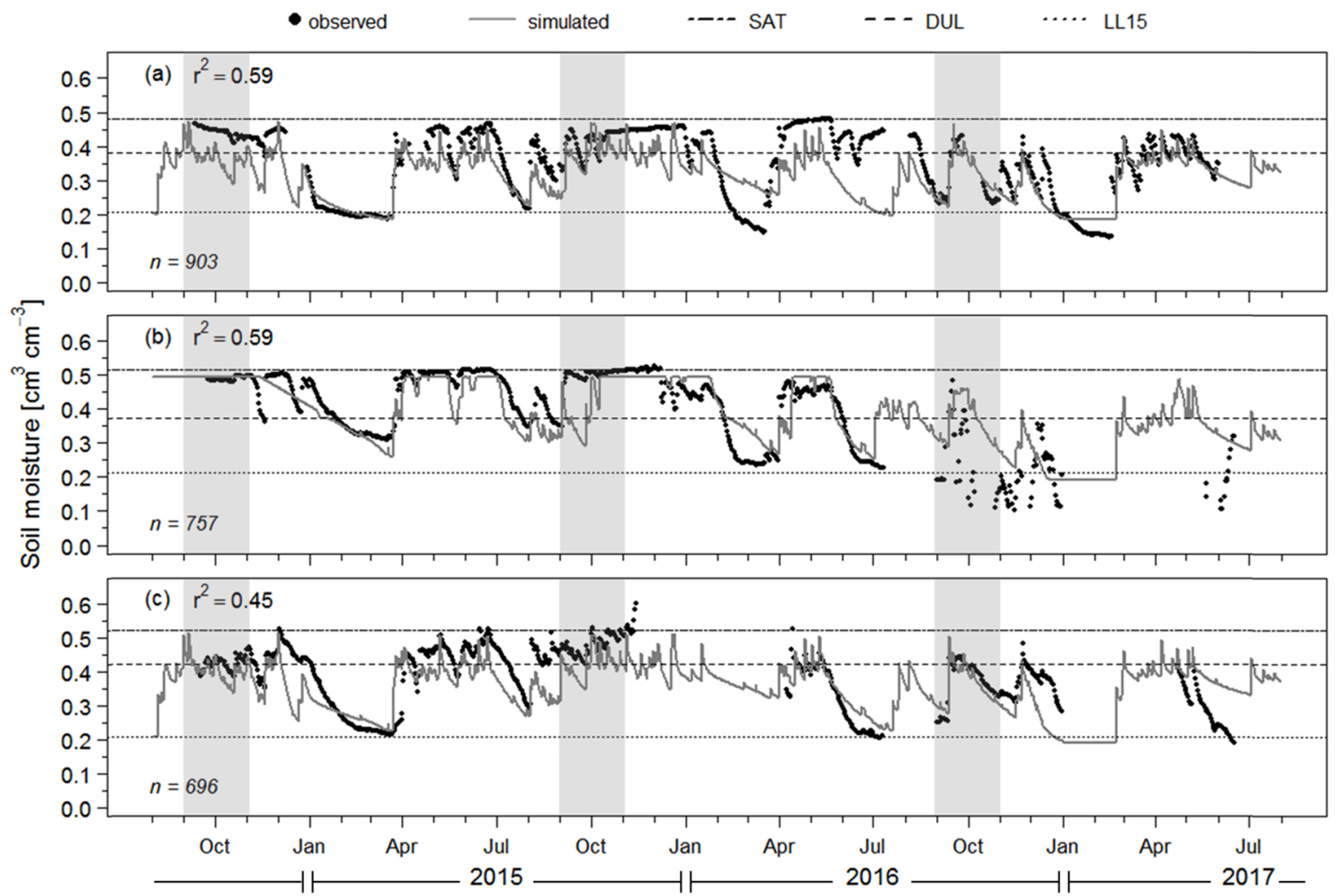

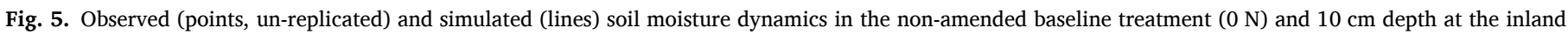

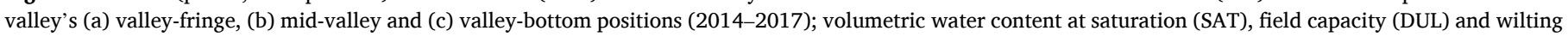
point (LL15); the shaded areas (grey) indicate the main rice-growing periods (September to November).

compared to $1.8-2.2 \mathrm{Mg} \mathrm{ha}^{-1}$ in the floodplain, $2.7 \mathrm{Mg}^{-1}$ compared to $1.8-1.9 \mathrm{Mg} \mathrm{ha}^{-1}$ in the inland valley), and reduce the current large yield gaps in floodplains (Senthilkumar et al., 2020) and inland valleys (Nhamo et al., 2014). Particularly bunding has been reported to reduce production risks from improved water retention during variable rainfall years in Tanzania (Raes et al., 2007). Additionally, bunding has been reported to increase yields by about $1 \mathrm{Mg} \mathrm{ha}^{-1}$ in an inland valley in Benin (Worou et al., 2013), and to improve rice N-responsiveness and reduce weed biomass in a small savanna valley in Côte d'Ivoire (Touré et al., 2009).

In both wetlands, yields showed significant responses to applied mineral $\mathrm{N}$ fertiliser while only yields in the floodplain's fringe were significantly higher than the middle position and no toposequential effect on yield was observed in the inland valley. The lack thereof is likely the result of greater intra- than inter-toposequential yield variability from high observed standard deviations that can be explained by heterogeneous soil properties, a microscale topography and large spatialtemporal fluctuations of shallow water tables (Gabiri et al., 2017). Therefore, yield pattern in the inland valley resulted from field- rather than toposequence-specific conditions, with differential responses to management and season as the seasonal rainfall variability was high (233-519 mm). Similar findings have been reported from inland valleys in the Indonesia and Thailand (Boling et al., 2008), and India (Cornish et al., 2020). Meanwhile, attainable yields of $>7.2 \mathrm{Mg} \mathrm{ha}^{-1}$ in the floodplain and of about $5.2 \mathrm{Mg} \mathrm{ha}^{-1}$ in the inland valley, were still substantially lower than simulated yield potentials of up to 10.5 and $7.3 \mathrm{Mg} \mathrm{ha}^{-1}$ in the floodplain and inland valley, respectively (Kwesiga et al., 2020b). Overall higher yields and yield responses to applied $\mathrm{N}$ fertiliser in the floodplain as compared to the inland valley were associated to more favourable rainfall and hydro-edaphic conditions and varietal differences, i.e., greater inherent yield potentials of the lowland rice $\mathrm{cv}$. SARO-5 as compared to the short-season, drought-resistant rainfed rice cv. NERICA- 4 .
However, the validated model can help to further differentiate the effects of hydro-edaphic field conditions on yield via spatial-temporal patterns of simulated water and $\mathrm{N}$ stress factors, and thus help guide management interventions (Inthavong et al., 2011) and assess risks to production (Boling et al., 2007). In both wetlands, $\mathrm{N}$ stress exceeded water stress but varied from edaphic conditions, while water stress was more pronounced in the inland valley than the floodplain. These findings correspond to other studies that identified soil $\mathrm{N}$ deficiency coupled with low external $\mathrm{N}$ fertiliser rates as a main constraint to lowland rice productivity in East Africa (Tsujimoto et al., 2019). Higher baseline yields in the wetlands' fringes were associated with lower $\mathrm{N}$ stress factors and correspond to more favourable topsoil C/N ratios. Furthermore, variations in soil aeration status could have stimulated SOM decomposition, resulting in higher soil N supply capacities (Kwesiga et al., 2019). Moderate application of $60 \mathrm{~kg} \mathrm{Nha}^{-1}$ resulted in significant and average yield gains of $>2$ and $>0.8 \mathrm{Mg} \mathrm{ha}^{-1}$ while $120 \mathrm{~kg} \mathrm{~N} \mathrm{ha}^{-1}$ and supplemental irrigation further increased yields by about 1.8 and $1.7 \mathrm{Mg} \mathrm{ha}^{-1}$ in the floodplain and in the inland valley, respectively. High N-responsiveness, particularly in the floodplain, was associated with sufficient soil $\mathrm{P}$ and $\mathrm{K}$ levels and the so-called priming effect in which applied $\mathrm{N}$ fertiliser helps overcome soil mineralisation barriers for increased plant $\mathrm{N}$ uptake (Liu et al., 2017). Similarly, Niang et al. (2018) reported that $\mathrm{N}$ rather than $\mathrm{P}$ and $\mathrm{K}$ limit yields in rainfed lowlands in Benin.

Generally lower water stress in the floodplain than the inland valley was associated with higher seasonal rainfall amounts $(562-1033 \mathrm{~mm})$ and higher water table supply capacities from greater hydraulic head gradients and soil water holding capacities (Bouman et al., 2007). Spatial-temporal water stress patterns, however, indicated that supplemental irrigation is likely most beneficial during the vegetative and early reproductive stages in the floodplain's fringe and during the late reproductive and ripening stages in the floodplain's middle position. In the inland valley, spatial-temporal water stress patterns suggested 

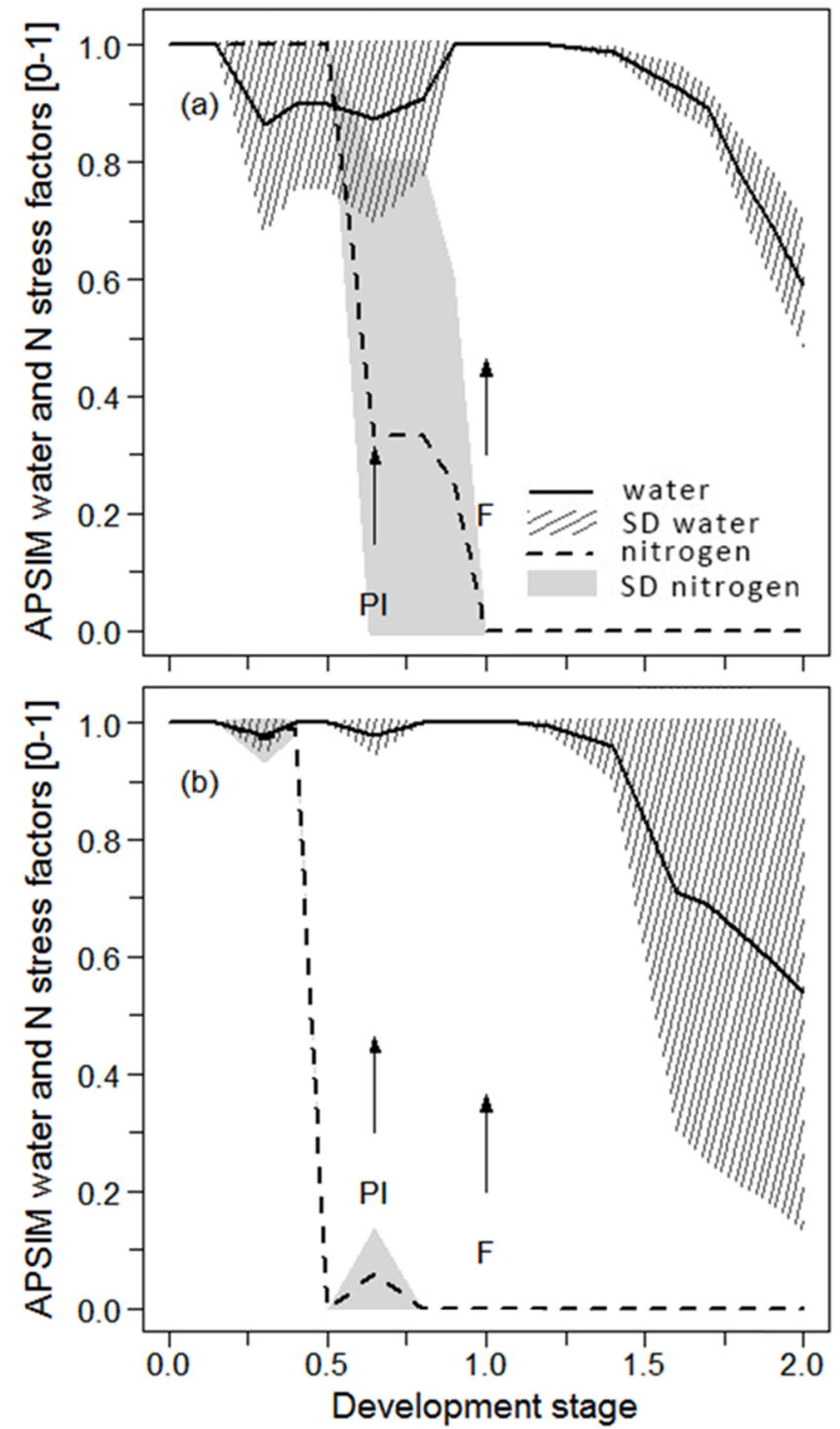

Fig. 6. Simulated mean factor for water (solid line) and N stress (dotted line) ( $1=$ no stress, $0=$ severe stress) and the standard deviation (SD) according to phenological development stage in the non-amended baseline treatment $(0 \mathrm{~N})$ at the floodplain's (a) fringe and (b) middle positions. Results based on the study period from 2015 to $2017(n=3)$. PI, panicle initiation; F, flowering.

beneficial effects of supplemental irrigation during the vegetative and reproductive stages in all field positions. However, the determination of both water and $\mathrm{N}$ stress factors inherently relies on experimentally-derived estimates in the model, i.e., the upper and lower soil-water tension limits for leaf expansion and potential crop $\mathrm{N}$ contents (Bouman et al., 2001). Therefore, they encompass a certain level of uncertainty when used for new edaphic conditions and varieties but would otherwise require extensive additional field data collection that would have gone beyond the resources of this study.

Additionally, hydrological processes linked to seasonally shallow water tables at both wetland types and field positions potentially entail differential risks to crop production (Osujieke et al., 2017), i.e., temporary drought-risk in the inland valley fringes and crop submergence risk in the floodplain's riparian from overbank flow. Subsurface interflows from adjacent mountain ranges and overbank flows from a direct hydraulic connection to the river control seasonally shallow water tables in the floodplain's fringe and middle position, respectively (Burghof et al., 2018). Therefore, the middle position is likely more prone to prolonged crop submergence with increasing river discharge amounts
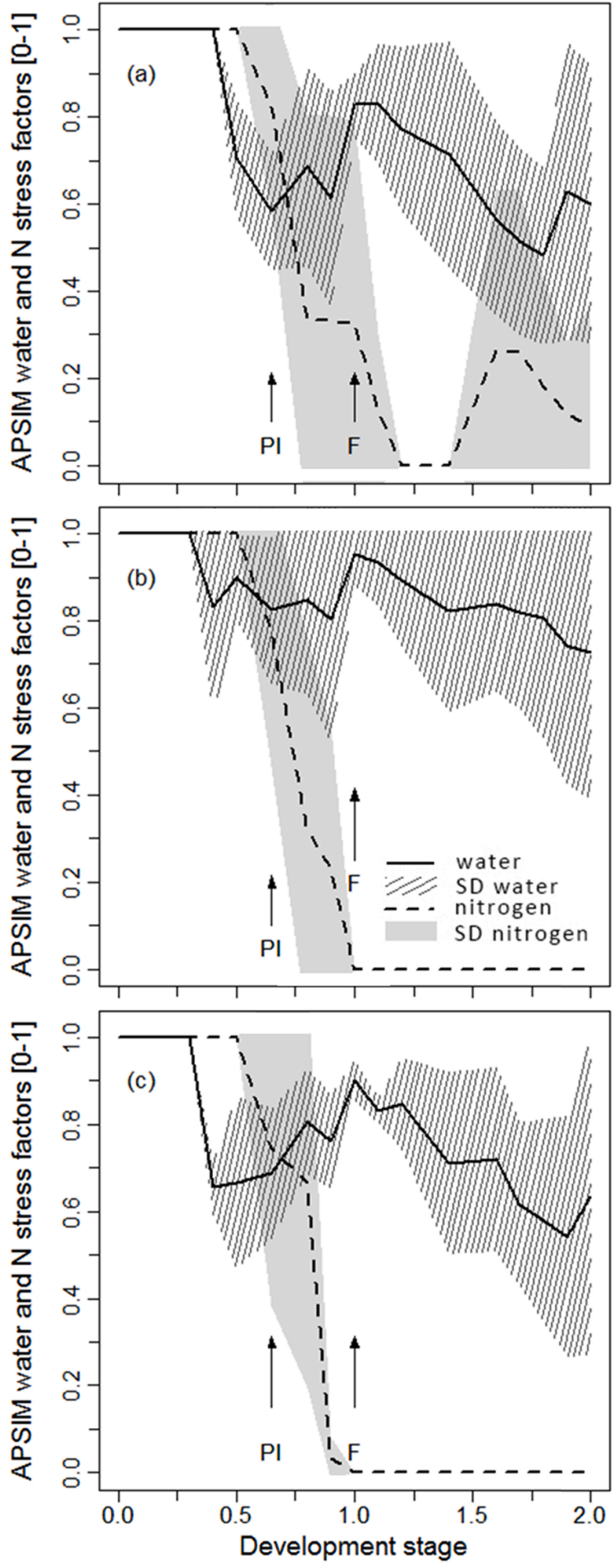

Fig. 7. Simulated mean factor for water (solid line) and $\mathrm{N}$ stress (dotted line) ( $1=$ no stress, $0=$ severe stress) and the standard deviation (SD) according to phenological development stage in the non-amended baseline treatment $(0 \mathrm{~N})$ at the inland valley's (a) valley-fringe, (b) mid-valley and (c) valley-bottom positions. Results based on the study period from 2014 to $2016(n=3)$. PI, panicle initiation; $\mathrm{F}$, flowering. 
and to more erratic water table fluctuations in response to river water levels (Gabiri et al., 2018). Unfavourable rainfall pattern and erratic water table fluctuations may thus explain the high variability of late-season water stress factors that could have affected yields from increased spikelet sterility (Boling et al., 2004). In the inland valley, seasonally shallow water tables resulted from lateral and subsurface inflows of adjacent valley slopes and local discharges from a deep groundwater table but showed high temporal and intra-toposequential variabilities and no distinct delineation (Gabiri et al., 2019). Particularly lateral inflows are potentially benefiting upper toposequence positions, while higher water availabilities are usually reported from lower toposequence positions (Tsubo et al., 2005). Additionally, Schmitter et al. (2015) ascertained higher production risks from prolonged crop submergence in the valley bottoms. However, no prolonged crop submergence was observed in the inland valley position during the study period which was likely the result of stream diversion for irrigation and/or drainage purposes from the original flow path and the subsequent effects on stream discharge amounts (Gabiri et al., 2017).

\section{Conclusion}

This study showed that APSIM performed well within the bounds of the experimental error simulating rice responses to management treatments and variable hydro-edaphic conditions in two East African wetlands, provided external water table data (measured or simulated) were available as model input. While hydro-edaphic field conditions favoured the floodplain's fringe position, the lack of toposequential effect on yield from large spatial-temporal variabilities in the inland valley implied that management recommendations should be field- not toposequencespecific. The validated model can subsequently help to evaluate longterm effects of management and hydro-edaphic field conditions on yield, yield variability and associated production risks, and thus help to identify trade-offs between agronomic efficiencies and economic incentives of $\mathrm{N}$ fertiliser use for widespread adoption. Since this study, however, was restricted to two discrete study sites, management by hydro-edaphic interactions will likely differ within other East African lowland rice systems.

\section{Declaration of Competing Interest}

The authors declare that they have no known competing financial interests or personal relationships that could have appeared to influence the work reported in this paper.

\section{Acknowledgement}

The authors acknowledge the funding received from the German Federal Ministry of Education and Research (BMBF) and the German Federal Ministry of Economic Cooperation and Development (BMZ) (Grant number FKZ 031A250 A-H), with additional funding by the German Research Foundation (DFG) (Grant number TRR 228/1). The authors are grateful to all colleagues of the 'GlobE: Wetlands in East Africa' project, in particular to Björn Glasner for the provision of soil profile data, and to Sonja Burghof and Geofrey Gabiri for water table and soil moisture data. The authors thank Maureen Namugalu, Jesca Nassolo, Nagirinya Justine, Lozio Makesa, John Massawe, Sam Okirya, Goodluck Munishi, Rashid Mutengela, Kayongo Augustine and others for their diligent assistance with field work and data collection. Constructive comments given by the reviewers to an earlier version of the manuscript are also acknowledged.

\section{Appendix A. Supporting information}

Supplementary data associated with this article can be found in the online version at doi:10.1016/j.agwat.2021.107146.

\section{References}

Amarasingha, R.P.R.K., Suriyagoda, L.D.B., Marambe, B., Rathanayake, W.M.U.K., Gaydon, D.S., Galagedara, L.W., Punyawardena, R., Silva, G.L.L.P., Nidumolu, U., Howden, M., 2017. Improving water productivity in moisture-limited rice-based cropping systems through incorporation of maize and mungbean: a modelling approach. Agric. Water Manag. 189, 111-122. https://doi.org/10.1016/j. agwat.2017.05.002.

Asseng, S., Keating, B.A., Fillery, I.R.P., Gregory, P.J., Bowden, J.W., Turner, N.C., Palta, J.A., Abrecht, D.G., 1998. Performance of the APSIM-wheat model in Western Australia. Field Crops Res. 57 (2), 163-179. https://doi.org/10.1016/S0378-4290 (97)00117-2.

Balasubramanian, V., Sie, M., Hijmans, R.J., Otsuka, K., 2007. Increasing rice production in sub-Saharan Africa: challenges and opportunities. Adv. Agron. 94, 55-133. https://doi.org/10.1016/S0065-2113(06)94002-4.

Singh, Balwinder, Humphreys, E., Gaydon, D.S., Eberbach, P.L., 2016. Evaluation of the effects of mulch on optimum sowing date and irrigation management of zero till wheat in central Punjab, India using APSIM. Field Crops Res. 197, 83-96. https:// doi.org/10.1016/j.fcr.2016.08.016.

Belder, P., Bouman, B.A.M., Spiertz, J.H.J., 2007. Exploring options for water savings in lowland rice using a modelling approach. Agric. Syst. 92 (1-3), 91-114. https://doi. org/10.1016/j.agsy.2006.03.001.

Boling, A.A., Tuong, T.P., Jatmiko, S.Y., Burac, M.A., 2004. Yield constraints of rainfed lowland rice in Central Java, Indonesia. Field Crops Res. 90 (2-3), 351-360. https:// doi.org/10.1016/j.fcr.2004.04.005.

Boling, A.A., Bouman, B.A.M., Tuong, T.P., Murty, M.V.R., Jatmiko, S.Y., 2007. Modelling the effect of groundwater depth on yield-increasing interventions in rainfed lowland rice in Central Java, Indonesia. Agric. Syst. 92 (1-3), 115-139. https://doi.org/10.1016/j.agsy.2006.05.003.

Boling, A.A., Tuong, T.P., Suganda, H., Konboon, Y., Harnpichitvitaya, D., Bouman, B.A. M., Franco, D.T., 2008. The effect of toposequence position on soil properties, hydrology, and yield of rainfed lowland rice in Southeast Asia. Field Crops Res. 106 (1), 22-33. https://doi.org/10.1016/j.fcr.2007.10.013.

Bouman, B.A.M., Van Laar, H.H., 2006. Description and evaluation of the rice growth model ORYZA2000 under nitrogen-limited conditions. Agric. Syst. 87, 249-273. https://doi.org/10.1016/j.agsy.2004.09.011.

Bouman, B.A.M., Kropff, M.J., Tuong, T.P., Wopereis, M.C.S., Ten Berge, H.F.M. and Van Laar, H.H. (2001). ORYZA2000: modeling lowland rice. International Rice Research Institute (IRRI)/Wageningen University and Research Centre, Los Baños, Philippines/Wageningen, Netherlands.

Bouman, B.A.M., Feng, L., Tuong, T.P., Lu, G., Wang, H., Feng, Y., 2007. Exploring options to grow rice using less water in northern China using a modelling approach: II. Quantifying yield, water balance components, and water productivity. Agric. Water Manag. 88, 23-33. https://doi.org/10.1016/j.agwat.2006.10.005.

Burghof, S., Gabiri, G., Stumpp, C., Chesnaux, R., Reichert, B., 2018. Development of a hydrogeological conceptual wetland model in the data-scarce north-eastern region of Kilombero Valley, Tanzania. Hydrogeol. J. 26 (1), 267-284. https://doi.org/ 10.1007/s10040-017-1649-2.

Cabangon, R.J., Tuong, T.P., Castillo, E.G., Bao, L.X., Lu, G., Wang, G.H., Cui, Y., Bouman, B.A.M., Li, Y., Chen, C., Wang, J., 2004. Effect of irrigation method and Nfertilizer management on rice yield, water productivity and nutrient-use efficiencies in typical lowland rice conditions in China. Paddy Water Environ. 2 (4), 195-206. https://doi.org/10.1007/s10333-004-0062-3.

Cornish, P.S., Kumar, A., Das, S., 2020. Soil fertility along toposequences of the East India plateau and implications for productivity and sustainability. Soil 6 (2), 325-336. https://doi.org/10.5194/soil-2019-92.

De Datta, S.K., 1981. Principles and Practices of Rice Production. Wiley, New York, USA.

Dinesen, L., 2016. Kilombero Valley Floodplain (Tanzania). In: Finlayson, C.M., Everard, M., Irvine, K., Middleton, A.B., Dinesen, L., Davidson, N.C. (Eds.), The Wetland Book. Springer, Dordrecht, Netherlands, pp. 1-8.

Dixon, A.B., Wood, A.P., 2003. Wetland cultivation and hydrological management in eastern Africa: matching community and hydrological needs through sustainable wetland use. Nat. Resour. Forum 27, 117-129. https://doi.org/10.1111/14778947.00047.

Dutta, S.K., Laing, A.M., Kumar, S., Gathala, M.K., Singh, A.K., Gaydon, D.S., Poulton, P. L., 2020. Improved water management practices improve cropping system profitability and smallholder farmers' incomes. Agric. Water Manag. 242 (1), 106411 https://doi.org/10.1016/j.agwat.2020.106411.

Feng, L., Bouman, B.A.M., Tuong, T.P., Cabangon, R.J., Li, Y., Lu, G., Feng, Y., 2007. Exploring options to grow rice using less water in northern China using a modelling approach. Agric. Water Manag. 88 (1-3), 1-13. https://doi.org/10.1016/j. agwat.2006.10.006.

Fukai, S., 1999. Phenology in rainfed lowland rice. Field Crops Res. 64 (1-2), 51-60. https://doi.org/10.1016/S0378-4290(99)00050-7.

Gabiri, G., Diekkrüger, B., Burghof, S., Näschen, K., Asiimwe, I., Bamutaze, Y., 2017. Determining hydrological regimes in an agriculturally used tropical inland valley wetland in central Uganda using soil moisture, groundwater, and digital elevation data. Hydrol. Process. 32 (3), 349-362. https://doi.org/10.1002/hyp.11417.

Gabiri, G., Burghof, S., Diekkrüger, B., Leemhuis, C., Steinbach, S., Näschen, K., 2018. Modeling spatial soil water dynamics in a tropical floodplain, East Africa. Water 10 (2), 191. https://doi.org/10.3390/w10020191.

Gabiri, G., Leemhuis, C., Diekkrüger, B., Näschen, K., Steinbach, S., Thonfeld, F., 2019. Modelling the impact of land use management on water resources in a tropical inland valley catchment of Central Uganda, East Africa. Sci. Total Environ. 653, 1052-1066. https://doi.org/10.1016/j.scitotenv.2018.10.430. 
Gabiri, G., Diekkrüger, B., Näschen, K., Leemhuis, C., Van der Linden, R., Majaliwa, J.-G., M, Obando, J.A., 2020. Impact of climate and land use/land cover change on the water resources of a tropical inland valley catchment in Uganda, East Africa. Climate 8 (7), 83. https://doi.org/10.3390/cli8070083.

Gaydon, D.S., Probert, M.E., Buresh, R.J., Meinke, H., Suriadi, A., Dobermann, A., Bouman, B.A.M., Timsina, J., 2012a. Rice in cropping systems - modelling transitions between flooded and non-flooded soil environments. Eur. J. Agron. 39, 9-24. https://doi.org/10.1016/j.eja.2012.01.003.

Gaydon, D.S., Probert, M.E., Buresh, R.J., Meinke, H., Timsina, J., 2012b. Modelling the role of algae in rice crop nutrition and soil organic carbon maintenance. Eur. J. Agron. 39, 35-43. https://doi.org/10.1016/j.eja.2012.01.004.

Gaydon, D.S., Balwinder-Singh, Wang, E., Poulton, P.L., Ahmad, B., Ahmed, F., Akhter, S., Ali, I., Amarasingha, R.P.R.K., Chaki, A.K., Chen, C., Kumar, P.V., Khan, A.S.M.M.R., Laing, A.M., Liu, L., Malaviachichi, M.A.P.W.K., Mohapatra, K.P., Muttaleb, M.A., Power, B., Radanielson, A.M., Rai, G.S., Rashid, M.H., Rathanayake, W.M.U.K., Sarker, M.M.R., Sena, D.R., Shamim, M., Subash, N., Suriadi, A., Suriyagoda, L.D.B., Wang, G.H., Wang, J., Yadav, R.K., Roth, C.H., 2017 Evaluation of the APSIM model in cropping systems of Asia. Field Crops Res. 204, 52-75. https://doi.org/10.1016/j.fcr.2016.12.015.

Gaydon, D.S., Radanielson, A.M., Chaki, A.K., Sarker, M.M.R., Rahman, M.A., Rashid, M H., Kabir, M.J., Khan, A.S.M.M.R., Gaydon, E.R., Roth, C.H., 2021. Options for increasing Boro rice production in the saline coastal zone of Bangladesh. Field Crops Res. 264, 108089 https://doi.org/10.1016/j.fcr.2021.108089.

Godwin, D.C., Singh, U., 1991. Modelling nitrogen dynamics in rice cropping systems. In: Deturk, P., Ponnamperuma, F.N. (Eds.), Rice Production on Acid Soils of the Tropics. Institute of Fundamental Studies, Kandy, Sri Lanka, pp. 287-294.

Haefele, S.M., Saito, K., N’Diaye, K.M.N., Mussgnug, F., Nelson, A., Wopereis, M.C.S., 2013. Increasing rice productivity through improved nutrient use in Africa. In: Wopereis, M.C.S., Johnson, D.E., Ahmadi, N., Tollens, E., Jalloh, A. (Eds.), Realizing Africa's Rice Promise. CAB International, Wallingford, UK, pp. 250-264.

Hagi-Bishow, M., Bonnell, R.B., 2000. Assessment of LEACHM-C Model for semi-arid saline irrigation. ICID J. (J. Irrig. Drain.) 49 (1), 29-42.

Haneishi, Y., Maruyama, A., Asea, G., Okello, S.E., Tsuboi, T., Takagaki, M., Kikuchi, M., 2013. Exploration of rainfed rice farming in Uganda based on a nationwide survey: regionality, varieties and yield. AJAR 8 (29), 4038-4048. https://doi.org/10.5897/ AJAR12.121.

Hoffmann, M.P., Jacobs, A., Whitbread, A.M., 2015. Crop modelling based analysis of site-specific production limitations of winter oilseed rape in northern Germany. Field Crops Res. 178, 49-62. https://doi.org/10.1016/j.fcr.2015.03.018.

Holzworth, D.P., Huth, N.I., deVoil, P.G., Zurcher, E.J., Herrmann, N.I., McLean, G., Chenu, K., Van Oosterom, E.J., Snow, V.O., Murphy, C., Fainges, J., Bell, L.W., Peake, A.S., Poulton, P.L., Hochman, Z., Thorburn, P.J., Gaydon, D.S., Dalgliesh, N. P., Rodriguez, D., Cox, H., Chapman, S.C., Doherty, A., Teixeira, E.I., Sharp, J., Cichota, R., Vogeler, I., Li, F.Y., Wang, E., Hammer, G.L., Robertson, M.J., Dimes, J. P., Whitbread, A.M., Hunt, J., Van Rees, H., McClelland, T., Carberry, P.S., Hargreaves, J.N.G., MacLeod, N., McDonald, C., Harsdorf, J., Wedgwood, S., Keating, B.A., 2014. APSIM - Evolution towards a new generation of agricultural systems simulation. Environ. Modell. Softw. 62, 327-350. https://doi.org/10.1016/ j.envsoft.2014.07.009.

Inthavong, T., Tsubo, M., Fukai, S., 2011. A water balance model for characterization of length of growing period and water stress development for rainfed lowland rice. Field Crops Res. 121 (2), 291-301. https://doi.org/10.1016/j.fcr.2010.12.019.

Jones, C.A., Kiniry, J.R., 1986. CERES-Maize: A Simulation Model of Maize Growth and Development. Texas A\&M University Press, College Station, Texas, USA.

Jones, C.A., Dyke, P.T., Williams, J.R., Kiniry, J.R., Benson, V.W., Griggs, R.H., 1991. EPIC: an operational model for evaluation of agricultural sustainability. Agric. Syst. 37 (4), 341-350. https://doi.org/10.1016/0308-521X(91)90057-H.

Jones, M.P., Dingkuhn, M., Aluko, G.K., Semon, M., 1997. Interspecific Oryza sativa L. x O. glaberrima Steud. progenies in upland rice improvement. Euphytica 94 (2), 237-246. https://doi.org/10.1023/A:1002969932224.

Kafiriti, E.M., Dondeyne, S., Msomba, S., Deckers, J., Raes, D., 2003. Variations in agronomic characteristics of irrigated rice varieties: lessons from participatory trials in South Eastern Tanzania. JFAE 1 (2), 273-277.

Kato, F., 2007. Development of a major rice cultivation area in the Kilombero Valley. Tanzan. Afr. Stud. Monogr. 36, 3-18. https://doi.org/10.14989/68498.

Keating, B.A., Carberry, P.S., Hammer, G.L., Probert, M.E., Robertson, M.J., Holzworth, D.P., Huth, N.I., Hargreaves, J.N.G., Meinke, H., Hochman, Z., McLean, G., Verburg, K., Snow, V.O., Dimes, J.P., Silburn, D.M., Wang, E., Brown, S., Bristow, K.L., Asseng, S., Chapman, S.C., McCown, R.L., Freebairn, D.M., Smith, C.J., 2003. An overview of APSIM, a model designed for farming systems simulations. Eur. J. Agron. 18, 267-288. https://doi.org/10.1016/S1161-0301(02)00108-9.

Kijima, Y., Ito, Y., Otsuka, K., 2012. Assessing the impact of training on lowland rice productivity in an African setting: evidence from Uganda. World Dev. 40 (8), 1610-1618. https://doi.org/10.1016/j.worlddev.2012.04.008.

Kwesiga, J., Grotelüschen, K., Neuhoff, D., Senthilkumar, K., Döring, T.F., Becker, M., 2019. Site and management effects on grain yield and yield variability of rainfed lowland rice in the Kilombero floodplain of Tanzania. Agronomy 9 (10), 632-648. https://doi.org/10.3390/agronomy9100632.

Kwesiga, J., Grotelüschen, K., Senthilkumar, K., Neuhoff, D., Döring, T.F., Becker, M., 2020a. Effect of organic amendments on the productivity of rainfed lowland rice in the Kilombero floodplain of Tanzania. Agronomy 10 (9), 1280. https://doi.org/ 10.3390/agronomy10091280.

Kwesiga, J., Grotelüschen, K., Senthilkumar, K., Neuhoff, D., Döring, T.F., Becker, M., 2020b. Rice Yield Gaps in Smallholder Systems of the Kilombero Floodplain in Tanzania. Agronomy 10 (8), 1135. https://doi.org/10.3390/agronomy10081135.
Leemhuis, C., Amler, E., Diekkrüger, B., Gabiri, G., Näschen, K., 2016. East African wetland-catchment data base for sustainable wetland management. PIAHS 374 , 123-128. https://doi.org/10.5194/piahs-374-123-2016.

Liu, X.-J.A., Van Groenigen, K.J., Dijkstra, P., Hungate, B.A., 2017. Increased plant uptake of native soil nitrogen following fertilizer addition - not a priming effect? Appl. Soil Ecol. 114, 105-110. https://doi.org/10.1016/j.apsoil.2017.03.011.

Miyamoto, K., Maruyama, A., Haneishi, Y., Matsumoto, S., Tsuboi, T., Asea, G., Okello, S. E., Takagaki, M., Kikuchi, M., 2012. NERICA cultivation and its yield determinants: the case of upland rice farmers in Namulonge, Central Uganda. J. Agric. Sci. 4 (6), 120-135. https://doi.org/10.5539/jas.v4n6p120.

Mohanty, M., Sinha, N.K., Somasundaram, J., McDermid, S.S., Patra, A.K., Singh, M., Dwivedi, A.K., Reddy, K.S., Rao, C.S., Prabhakar, M., Hati, K.M., Jha, P., Singh, R.K., Chaudhary, R.S., Kumar, S.N., Tripathi, P., Dalal, R.C., Gaydon, D.S., Chaudhari, S. K., 2020. Soil carbon sequestration potential in a Vertisol in central India- results from a 43-year long-term experiment and APSIM modeling. Agric. Syst. 184, 102906 https://doi.org/10.1016/j.agsy.2020.102906.

Moritz, S., Bartz-Beielstein, T., 2017. imputeTS: time series missing value imputation in R. R J. 9 (1), 207. https://doi.org/10.32614/rj-2017-009.

Näschen, K., Diekkrüger, B., Leemhuis, C., Steinbach, S., Seregina, L., Thonfeld, F., Van der Linden, R., 2018. Hydrological modeling in data-scarce catchments: the Kilombero floodplain in Tanzania. Water 10 (5), 599. https://doi.org/10.3390/ w10050599.

Nasrin, S., Bergman, L.J., Jirström, M., Holmquist, B., Andersson Djurfeldt, A., Djurfeldt, G., 2015. Drivers of rice production: evidence from five sub-Saharan African countries. Agric. Food Secur. 4 (1), 1-19. https://doi.org/10.1186/s40066015-0032-6.

Nhamo, N., Rodenburg, J., Zenna, N., Makombe, G., Luzi-Kihupi, A., 2014. Narrowing the rice yield gap in East and Southern Africa: using and adapting existing technologies. Agric. Syst. 131, 45-55. https://doi.org/10.1016/j.agsy.2014.08.003.

Niang, A., Becker, M., Ewert, F., Tanaka, A., Dieng, I., Saito, K., 2018. Yield variation of rainfed rice as affected by field water availability and $\mathrm{N}$ fertilizer use in Central Benin. Nutr. Cycl. Agroecosyst. 110 (2), 293-305. https://doi.org/10.1007/s10705017-9898-y.

Nsubuga, F.N.W., Olwoch, J.M., Rautenbach, C.W. de, 2011. Climatic trends at Namulonge in Uganda: 1947-2009. IGG 3 (1), 119-131. https://doi.org/10.5539/ jgg.v3n1p119.

Osujieke, D.N., Imadojemu, P.E., Igbojionu, J.N., 2017. Characterization and variability of soils formed on a toposequential floodplain in Uratta, South Eastern Nigeria. FTSTJ 2 (1), 628-632.

Probert, M.E., Dimes, J.P., Keating, B.A., Dalal, R.C., Strong, W.M., 1998. APSIM's water and nitrogen modules and simulation of the dynamics of water and nitrogen in fallow systems. Agric. Syst. 56 (1), 1-28. https://doi.org/10.1016/S0308-521X(97) 00028-0.

Raes, D., Kafiriti, E.M., Wellens, J., Deckers, J., Maertens, A., Mugogo, S., Dondeyne, S., Descheemaeker, K., 2007. Can soil bunds increase the production of rain-fed lowland rice in South Eastern Tanzania? Agric. Water Manag. 89 (3), 229-235. https://doi. org/10.1016/j.agwat.2007.01.005.

Rodenburg, J., 2013. Inland Valleys: Africa's future food baskets. In: Wopereis, M.C.S Johnson, D.E., Ahmadi, N., Tollens, E., Jalloh, A. (Eds.), Realizing Africa's Rice Promise. CAB International, Wallingford, UK, pp. 276-293.

Rodenburg, J., Saito, K., Irakiza, R., Makokha, D.W., Onyuka, E.A., Senthilkumar, K., 2015. Labor-saving weed technologies for lowland rice farmers in sub-Saharan Africa. Weed Technol. 29 (4), 751-757. https://doi.org/10.1614/WT-D-15-00016.1.

Ruane, A.C., Goldberg, R., Chryssanthacopoulos, J., 2015. Climate forcing datasets for agricultural modeling: Merged products for gap-filling and historical climate series estimation. Agric. Meteorol. 200, 233-248. https://doi.org/10.1016/j. agrformet.2014.09.016

Saito, K., Nelson, A., Zwart, S.J., Niang, A., Sow, A., Yoshida, H., Wopereis, M.C.S., 2013. Towards a better understanding of biophysical determinants of yield gaps and the potential for expansion of the rice area in Africa. In: Wopereis, M.C.S., Johnson, D.E., Ahmadi, N., Tollens, E., Jalloh, A. (Eds.), Realizing Africa's Rice Promise. CAB International, Wallingford, UK, pp. 188-203.

Saito, K., Vandamme, E., Johnson, J.-M., Tanaka, A., Senthilkumar, K., Dieng, I., Akakpo, C., Gbaguidi, F., Segda, Z., Bassoro, I., Lamare, D., Gbakatchetche, H., Abera, B.B., Jaiteh, F., Bam, R.K., Dogbe, W., Sékou, K., Rabeson, R., Kamissoko, N., Mossi, I.M., Tarfa, B.D., Bakare, O.S., Kalisa, A., Baggie, I., Kajiru, G.J., Ablede, K.A., Ayeva, T., Nanfumba, D., Wopereis, M.C.S., 2019. Yield-limiting macronutrients for rice in sub-Saharan Africa. Geoderma 338, 546-554. https://doi.org/10.1016/j. geoderma.2018.11.036.

Schmitter, P., Zwart, S.J., Danvi, A., Gbaguidi, F., 2015. Contributions of lateral flow and groundwater to the spatio-temporal variation of irrigated rice yields and water productivity in a West-African inland valley. Agric. Water Manag. 152, 286-298. https://doi.org/10.1016/j.agwat.2015.01.014.

Senthilkumar, K., Tesha, B.J., Mghase, J.J., Rodenburg, J., 2018. Increasing paddy yields and improving farm management: results from participatory experiments with good agricultural practices (GAP) in Tanzania. Paddy Water Environ. 16 (4), 749-766. https://doi.org/10.1007/s10333-018-0666-7.

Senthilkumar, K., Rodenburg, J., Dieng, I., Vandamme, E., Sillo, F.S., Johnson, J.-M., Rajaona, A., Ramarolahy, J.A., Gasore, E.R., Abera, B.B., Kajiru, G.J., Mghase, J.J., Rabeson, R., Lamo, J., Saito, K., 2020. Quantifying rice yield gaps and their causes in Eastern and Southern Africa. J. Agron. Crop Sci. 206, 478-490. https://doi.org/ 10.1111/jac.12417.

Senthilkumar, K., Sillo, F.S., Rodenburg, J., Dimkpa, C.O., Saito, K., Dieng, I. Bindraban, P.S., 2021. Rice yield and economic response to micronutrient application in Tanzania. Field Crops Res. 270, 108201 https://doi.org/10.1016/j. fcr.2021.108201. 
Šimůnek, J., Šejna, M., Saito, H., Sakai, M., Van Genuchten, M.T., 2013. The HYDRUS-1D Software Package for Simulating the One-Dimensional Movement of Water, Heat, and Multiple Solutes in Variably Saturated Media, Manual Version 4.17. University of California, Riverside, California, USA.

Singh, R.K., Murori, R., Ndayiragije, A., Bigirimana, J., Kimani, J.M., Kanyeka, Z.L., Surpong, S., Singh, Y.P., 2013. Rice breeding activities in Eastern and Southern Africa. SABRAO J. Breed. Genet. 45 (1), 73-83.

Touré, A.A., Becker, M., Johnson, D.E., Koné, B., Kossou, D.K., Kiepe, P., 2009. Response of lowland rice to agronomic management under different hydrological regimes in an inland valley of Ivory Coast. Field Crops Res. 114 (2), 304-310. https://doi.org/ 10.1016/j.fcr.2009.08.015.

Tsubo, M., Fukai, S., Basnayake, J., Tuong, T.P., Bouman, B.A.M., Harnpichitvitaya, D., 2005. Estimating percolation and lateral water flow on sloping land in rainfed lowland rice ecosystem. Plant Prod. Sci. 8 (3), 354-357. https://doi.org/10.1626/ pps.8.354.

Tsubo, M., Basnayake, J., Fukai, S., Sihathep, V., Siyavong, P., Sipaseuth, Chanphengsay, M., 2006. Toposequential effects on water balance and productivity in rainfed lowland rice ecosystem in Southern Laos. Field Crops Res. 97 (2-3), 209-220. https://doi.org/10.1016/j.fcr.2005.10.004.
Tsujimoto, Y., Rakotoson, T., Tanaka, A., Saito, K., 2019. Challenges and opportunities for improving $\mathrm{N}$ use efficiency for rice production in sub-Saharan Africa. Plant Prod. Sci. 22 (4), 413-427. https://doi.org/10.1080/1343943X.2019.1617638.

van Campenhout, B., Walukano, W. and van Asten, P.J.A. (2016). Addressing knowledge gaps in rice growing in eastern Uganda. International Food Policy Research Institute (IFPRI), Washington DC, USA.

Willmott, C.J., Matsuura, K., 2005. Advantages of the mean absolute error (MAE) over the root mean square error (RMSE) in assessing average model performance. Clim. Res. 30 (1), 79-82. https://doi.org/10.3354/cr030079.

Worou, N.O., Gaiser, T., Saito, K., Goldbach, H., Ewert, F., 2012. Simulation of soil water dynamics and rice crop growth as affected by bunding and fertilizer application in inland valley systems of West Africa. Agric. Ecosyst. Environ. 162, 24-35. https:// doi.org/10.1016/j.agee.2012.07.018.

Worou, N.O., Gaiser, T., Saito, K., Goldbach, H., Ewert, F., 2013. Spatial and temporal variation in yield of rainfed lowland rice in inland valley as affected by fertilizer application and bunding in north-west Benin. Agric. Water Manag. 126, 119-124. https://doi.org/10.1016/j.agwat.2013.04.007. 